\section{Pacific Northwest}

National Laboratory

Operated by Battelle for the

U.S. Department of Energy

\title{
Roadmap for Integrating Sustainable Design into Site-Level Operations
}

K. L. Peterson

J. A. Dorsey

March 2000

Prepared for the U.S. Department of Energy under Contract DE-AC06-76RLO 1830 


\title{
DISCLAIMER
}

This report was prepared as an account of work sponsored by an agency of the United States Government. Neither the United States Government nor any agency thereof, nor Battelle Memorial Institute, nor any of their employees, makes any warranty, express or implied, or assumes any legal liability or responsibility for the accuracy, completeness, or usefulness of any information, apparatus, product, or process disclosed, or represents that its use would not infringe privately owned rights. Reference herein to any specific commercial product, process, or service by trade name, trademark, manufacturer, or otherwise does not necessarily constitute or imply its endorsement, recommendation, or favoring by the United States Government or any agency thereof, or Battelle Memorial Institute. The views and opinions of authors expressed herein do not necessarily state or reflect those of the United States Government or any agency thereof.

\author{
PACIFIC NORTHWEST NATIONAL LABORATORY \\ operated by \\ BATTELLE \\ for the \\ UNITED STATES DEPARTMENT OF ENERGY \\ under Contract DE-AC06-76RLO 1830
}

Printed in the United States of America

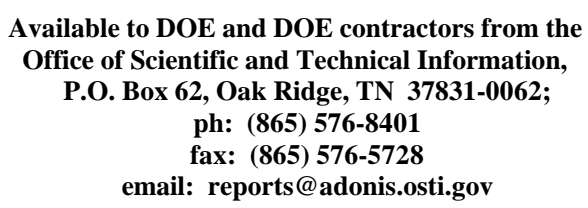

Available to the public from the National Technical Information Service,

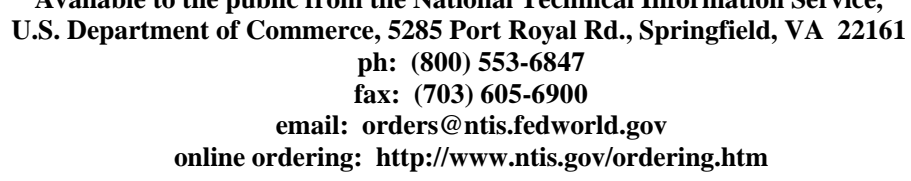

While we have made every effort to provide accurate citing of all references to Internet site URLs in this document, we cannot ensure these sites will remain active or accessible.

(3) This document was printed on recycled paper. 


\section{Roadmap for Integrating} Sustainable Design into Site-Level Operations

\section{K. L. Peterson}

\section{J. A. Dorsey ${ }^{(a)}$}

March 2000

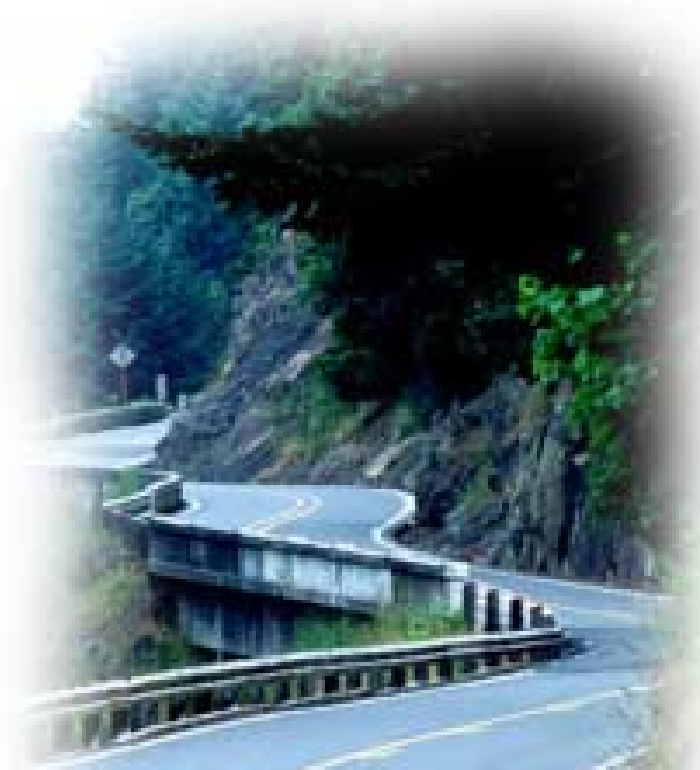

Prepared for

the U.S. Department of Energy

under Contract DE-AC06-76RLO 1830

Pacific Northwest National Laboratory

Richland, Washington 99352

(a) The Brendle Group, Inc., Ft. Collins, Colorado 
"The Department can lower the future operating costs of our facilities by incorporating pollution prevention and energy efficiency(P2/E2) into the design and modification of all buildings and during all operations."

\author{
Bill Richardson, Secretary of Energy \\ (February 26, 1999)
}




\section{Executive Summary}

This document presents a roadmap for integrating sustainable design (SD) at U.S. Department of Energy sites. Sustainable design is the systematic consideration, during the design process, of an activity, project, or product's life cycle impacts on the sustainable use of environmental and energy resources. Employing SD provides a way to ensure facility design, construction, operations, and decommissioning are safe, energy efficient, and environmentally responsible. The strategy outlined in this Roadmap suggests three levels of integration (program management planning, site infrastructure, and design project) for implementing SD into facility design activities. The guidance given here considers that SD integration will be customized to account for each site's unique characteristics and needs.

\section{Acknowledgiments}

We, the authors, would like to thank the people who helped make this document possible. In particular, special thanks to John Lum, DOE Office of Technical Program Integration, for his championship of the adoption of Sustainable Design in DOE and constant leadership in preparation of this Roadmap. The many people who have worked with us over the years on the DOE Pollution Prevention by Design project — including Elizabeth Raney, Mary Betsch, Bill Brown, Ronald Del-Mar, Jill Engel-Cox, Kim Fowler, Frank Greitzer, Tapio Kuusinen, Sallie Ortiz, Paul Otis, and John Warren — collectively provided the foundation of data and insights that showed the need for this document. We also wish to thank Keith Trychta at Argonne National Laboratory; John Griffin at Idaho National Engineering \& Environmental Laboratory; and Keith Stone at Savannah River Site, along with the Facilities Engineering Staff at their respective sites, for testing integration of beta versions of the Roadmap at their sites. Thank you, too, to the many individuals across DOE who contributed their valuable time to review and comment on the document, including: John Marchetti, Jeff Short, William Boettinger, Chris Hammons, Jack Mizner, and others who, though unmentioned, are not forgotten. 


\section{Contents}

Executive Summary ................................................................................................................... iii

Acknowledgments ....................................................................................................................... iii

1 Introduction ...................................................................................................................... 1-1

1.1 Purpose and Strategy of the Roadmap ..........................................................1-1

1.2 Sustainable Design Definition and Principles ………………………………....1-3

2 Sustainable Design Program Management Plan ........................................................ 2-1

2.1 Perform a Baseline Assessment and Gap Analysis .......................................... 2-1

2.2 Establish SD Integration Goals .....................................................................2-2

2.3 Follow an Action Plan....................................................................................2-2

2.4 Conduct Annual SD Performance and Test Reviews ........................................ 2-3

3 Integrating Sustainable Design into Site Infrastructure ....................................... 3-1

3.1 Integrate SD into Site Environmental Policy .................................................... 3-1

3.2 Ensure SD Performance Agreements Are Integrated into Site Contractor Requirements .................................................................... 3-2

3.3 Revise Site Operating Procedures to Promote SD .............................................. 3-3

3.4 Provide Site-Level SD Training ..................................................................... 3-4

3.5 Revise Applicable Architecture and Engineering Standards and Specifications ....................................................... 3-5

4 Sustainable Design Implementation at the Project Level....................................... 4-1

4.1 Project Level Integration Parameters............................................................. 4-1

4.2 Graded Level of Implementation ................................................................. 4-7

4.3 Integration into Project Cost Baselines ............................................................ 4-8

4.4 The Pollution Prevention Design Assessment …………………………….... 4-10

4.5 Architecture and Engineering Subcontractor Incentives …………………..... 4-13

4.6 Project-Level Integration Checklist .............................................................. 4-14

Appendix A: References and Additional Resources ..................................................... A-1

A.1 Design for Environmental (DfE) - General ……………………………….....A-1

A.2 Environmentally Preferred Materials............................................................ A-1

A.3 Green Design Manuals and Case Studies ………………………………...... A-2

A.4 Software Products ................................................................................ $A$-3

A.5 Internet Resources and Citations ............................................................... A-4

A.6 Regulations, DOE Orders, and Procedures Governing Design ........................ A-5

A.7 Example DOE Projects That Have Implemented Sustainable Design..............A-6

A.8 Annotated Matrix of Project-Level SD Resources ………………………….... A-8

A.9 Acronyms Used in the Main Text ............................................................. A-12 


\section{Contents (continued)}

Appendix B: Supporting Documentation ............................................................ B-1

B.1 Memorandum of Understanding and Agreement Among the DOE, the EPA, and the GSA ….....................................................................

B.2 February 26, 1999 Memorandum for Heads of Departmental Elements

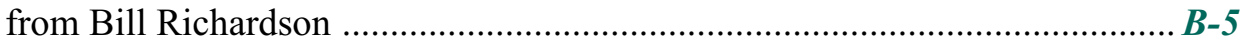

B.3 The P2 by Design Draft Performance Measures:

Energy Management and Pollution Prevention Performance

Based Objectives, Measures, and Expectations ............................................. B-6

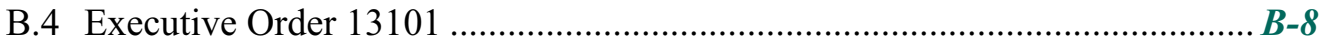

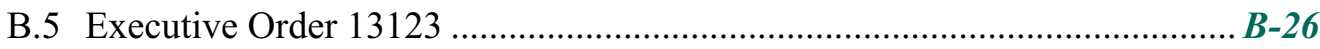

\section{Figures}

1. Roadmap for Integrating Sustainable Design at DOE Sites ................................. 1-2

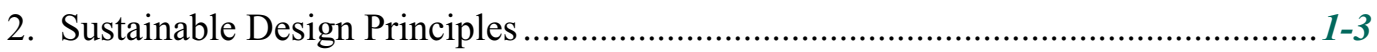

3. Sustainable Design Integration Parameters ........................................................... 2-1

4. Project-Level Integration Parameters ................................................................. 4-1

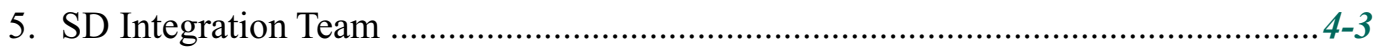

6. The Process Steps of a Pollution Prevention Design Assessment .......................... 4-10

7. The Project-Level Sustainable Design Integration Checklist ............................... 4-15 


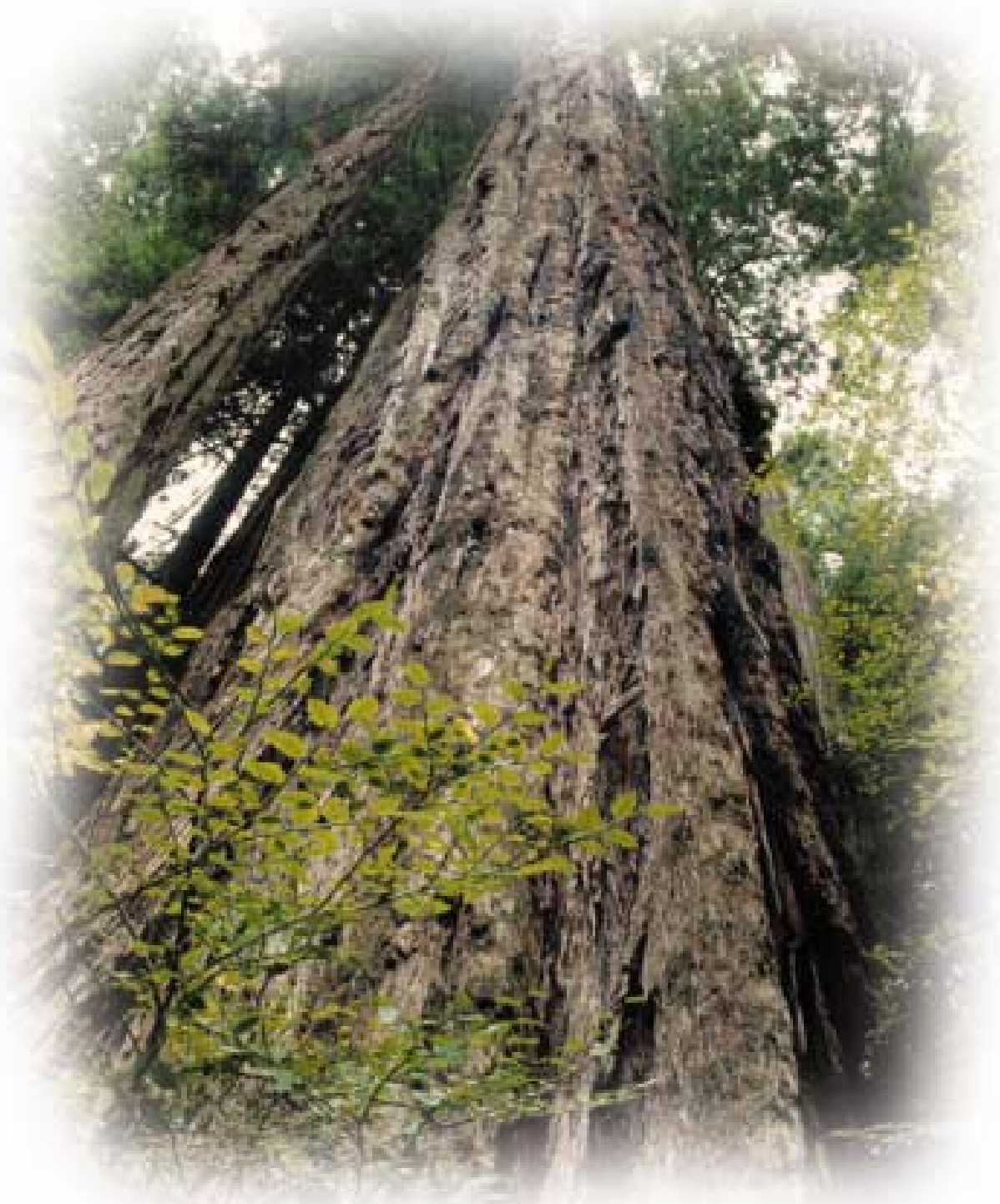

Sustainable Design recognizes that products and processes are interdependent with the environmental, economic, and social systems surrounding them and implements measures to prevent an unsustainable compromise to these systems. 


\section{Introduction}

Pollution prevention and energy efficiency (P2/E2) has become a powerful tool and prudent business practice for cutting the rising costs of waste management over the life of a facility, including facilities throughout the U.S. Department of Energy (DOE) complex. In addition to enhancing environmental quality, practicing P2/E2 also creates a positive public perception.

On December 8, 1998, the DOE joined in a Memorandum of Understanding and Agreement with the U.S. Environmental Protection Agency (EPA) and the General Services Administration (GSA) to "Build Green," employing "sustainable design principles to all phases of Federal facilities - initial design, construction, remodeling, renovation and construction waste management." Also, the U.S. Secretary of Energy sent a memorandum (attached in Appendix B) on February 24, 1999, directing the DOE to incorporate "pollution prevention and energy efficiency (P2/E2) into the design and modification of all buildings and during all operations."

On June 3, 1999, the President signed Executive Order (EO) 13123 (attached in Appendix B) to promote energy efficiency in Federal buildings. This EO specifically identifies sustainable design as a strategy to meet energy efficiency goals. Another Executive Order, EO 13101, signed by the President on September 12, 1998, required that waste prevention, use of environmentally preferable products, and elimination of virgin material requirements be considered during Federal acquisition planning.

These are just a few of the drivers that define the trend for facility design. Sustainable design (SD) is becoming the preferred method to

\begin{tabular}{|c|}
\hline Sustainability is the \\
continued ability of a \\
society, ecosystem, or any \\
such interactive system to \\
function without \\
exhausting key resources \\
and without adversely \\
affecting the environment.
\end{tabular}
ensure facility design, construction, operations, and decommissioning are safe, energy efficient, and environmentally responsible. To successfully respond to these drivers, each DOE organization and Operations Office must actively seek out and fund beneficial SD opportunities that enhance environmental quality and save taxpayer dollars. A new facility can dramatically reduce waste generation levels and waste management costs and increase energy efficiency over its life span when SD options are incorporated during the design phase. Several Operations Offices have begun to adopt better management practices that take into account full life cycle impacts rather than just construction costs.

\subsection{Purpose and Strategy of the Roadmap}

The purpose of this roadmap document is to provide guidance and support that will help facilitate the transition of SD into the culture of site facility design practices. The SD principles are briefly defined in Section 1.2. Each site must determine how to incorporate these principles into its unique activities. Several ongoing initiatives within DOE can be 
used to demonstrate ways that SD can be incorporated into facility design projects.

Examples of programs or activities that complement SD are listed below:

- The Integrated Safety Management System, which provides a comprehensive and systematic approach to undertaking any initiative.

- Environmental Management systems (in conformance, for example, with the ISO 14001 standard) that establish how a site will assure the health and safety of its personnel while protecting the environment.

- Affirmative Procurement and Environmental Preferred Procurement requirements that provide for buying recyclable and recycled items.

- Life Cycle Asset Management activities that incorporate a recognition of cradle-tograve costs in decisions.

- Waste prevention programs that call for elimination of wastes and pollutants at the source and utilization of renewable and recycled content items.

- Global warming alleviation activities, such as the Ozone Depletion Substance Phaseout program and energy efficiency programs.

The Roadmap outlines a process that can be used to review facility design activities at DOE sites, and identify opportunities for SD integration. This document suggests three levels of integration that collectively ensure the systematic adoption of SD into facility design activities:

\section{Figure 1. Roadmap for Integrating Sustainable Design at DOE Sites}

Sustainable Design Program Management Strategy (see Chapter 2)

- Perform Baseline Assessment and Gap Analysis

- Establish Integration Goals

- Implement Action Plan

- Demonstrate Performance

...to address the following SD integration parameters:

Site Infrastructure Integration Parameters (see Chapter 3)

- Policy

- Site Contractor Performance Agreements

- Site Operating Procedures

- Training

- Architecture and Engineering Standards and Specifications

Project-Level Integration Parameters (see Chapter 4)

- Project Charter

- Budget Planning

- Project Team Leadership

- Training

- Conceptual Design Documentation

- Integration with Existing Project Design Processes

- Project Cost Baselines

- Pollution Prevention Design Assessment

- Architecture and Engineering Subcontracts

- Facility Operations and Decommissioning
1. The program management planning level, which gives a framework for assessing existing activities, and then, through a gap analysis, identifying areas where improvements can be accomplished.

2. The site infrastructure level, which covers the administrative systems and operations required to perform facility design projects.

3. The design project level, where the specific design elements are defined for individual facility projects.

Within the infrastructure and project levels, the Roadmap identifies several parameters of opportunity to incorporate SD at that level. Fig. 1 shows a checklist overview of the process. Each of these levels of integration is described in greater detail in Chapters 2 through 4. 


\subsection{Sustainable Design Definition and Principles}

This document provides a strategy for effectively integrating SD into site facility design practices. It does not provide prescriptive requirements and standards for SD. There are numerous, very good resources that further discuss and define SD principles, standards, and methods. Further information about these resources is included in Appendix A. However, for clarification, some definitions and SD principles are summarized below.

Sustainability: The ability of a society, ecosystem, or any such interactive system to continue functioning into the indefinite future without being forced into decline through the exhaustion of key resources and without having a significant detrimental effect on the environment. Overuse or non-renewable use of resources will eventually decrease future productivity, thereby lowering sustainable yields. Even if the resources are abundant, systems that rely on certain resources may not be sustainable if this resource consumption results in cumulative environmental impacts.

\section{Sustainable Design (SD):}

The systematic consideration, during design, of an activity, project, or product's life cycle impacts on the sustainable use of environmental and energy resources. The overarching tenet of sustainable design is to use resources efficiently and within their renewable limits. Sustainable design recognizes that products and processes are interdependent with the environmental, economic, and social systems surrounding them; follows design principles (see Fig. 2) that respect these connections; and implements measures to prevent an unsustainable compromise to these systems.

\section{Figure 2. Sustainable Design Principles}

SD principles include, but are not limited to:

1. Increase energy and water efficiency and conservation.

2. Increase use of renewable energy resources.

3. Reduce or eliminate toxic and hazardous substances in facilities, processes, and their surrounding environment.

4. Improve indoor air quality and interior and exterior environments leading to increased human productivity and performance and better human health.

5. Use resources and material efficiently.

6. Select materials and products that would minimize safety hazards and cumulative environmental impacts.

7. Increase use of recycled content and other environmentally preferred products.

8. Salvage and recycle construction waste and building materials during construction and during demolition.

9. Prevent the generation of harmful materials and emissions during construction, operation, and decommissioning/demolition.

10. Implement maintenance and operational practices that reduce or eliminate harmful effects on people and the natural environment.

11. Reuse existing infrastructure, locate facilities near public transportation, and consider redevelopment of contaminated properties.

Sustainable Building Design: Two references in particular are becoming the standard for defining SD principles as they apply to buildings and facilities. First, the U.S. Green Building Council has developed the LEED ${ }^{\mathrm{TM}}$ Green Building Rating System to evaluate a building's environmental performance from a "whole building" perspective over its life cycle. The LEED system is based on accepted energy and environmental principles, and attempts to strike a balance between known effective practices and emerging concepts. Under LEED, the level of SD integrated into facilities is rated under the following categories:

- planning sustainable sites

- improving energy efficiency 
- conserving materials and resources

- enhancing indoor environmental quality

- safeguarding water

- improving the design/build process.

Further information about the LEED Green Building Rating System can be found at the U.S. Green Building Council, http://www.usgbc.org/.

Second, for the Federal sector, a Federal Interagency task force formed in compliance with EO 13123 and co-chaired by the GSA and the U.S. Department of Defense, organized a set of Principles of Sustainable Design and Development into categories consistent with the LEED

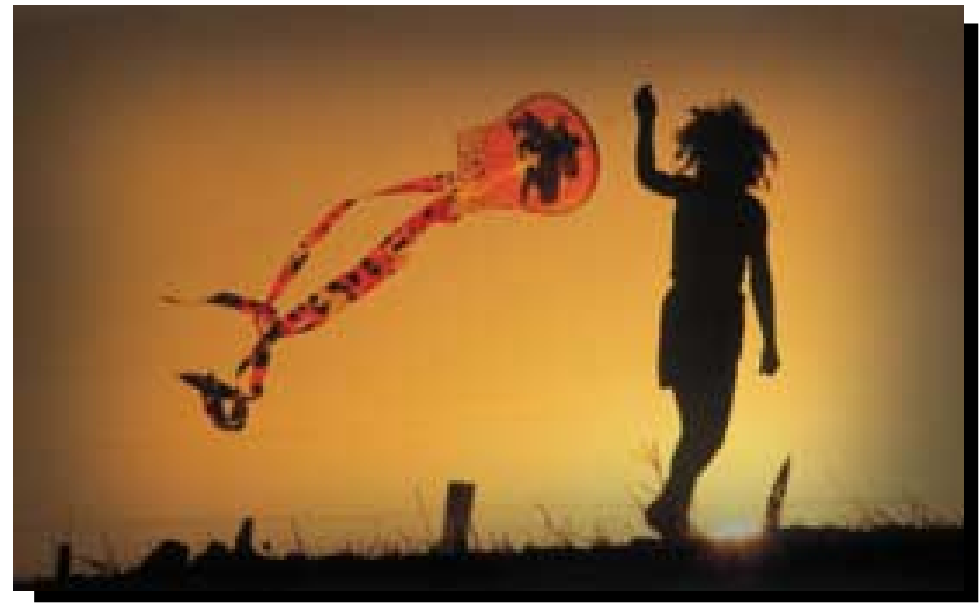
rating system. The principles address a facility's

- site location

- energy

- materials

- water

- indoor environmental quality

- operations and maintenance.

Further details on the Principles of Sustainable Design and Development are contained in the Whole Building Design Guide, http://www.wbdg.org/ sustainability/index.htm.

Within DOE, the Federal Energy Management Program (FEMP), under the Office of Energy Efficiency and Renewable Energy, has taken the lead in ensuring compliance with the SD expectations identified in EO 13123. A listing of the FEMP technical assistance resources and tools is available at http://www.eren.doe.gov/femp. DOE also has a set of SD tools (available at http://www.pnl.gov/doesustainabledesign/) that provide guidance for sustainable production, research, and clean-up operations as well as SD for buildings. 
Successful Sustainable Design integration

begins with using sound

program management practices. 


\section{Sustainable Design Program Management Plan}

Successful SD integration begins with using sound program management practices. A standardized program management planning approach is recommended to encourage consistent deployment of SD across the complex. The planning methodology defined here has been demonstrated (FY 1998) to be very effective in identifying and integrating SD opportunities at several DOE sites, including Savannah River, Argonne National Laboratory, and Idaho National Engineering and Environmental Laboratory. This methodology consists of four general steps:

1. Perform an SD baseline assessment and gap analysis.

2. Establish SD integration goals for the site.

3. Follow an action plan to meet the SD goals.

4. Perform annual self-assessments to confirm progress on the action plan.

The benefit of this deployment strategy is that it allows each field office the flexibility to customize $\mathrm{SD}$ integration to address the unique characteristics and needs of individual sites. It also provides the framework to capture the activities and systems already in place that promote integrating SD into facility projects.

\subsection{Perform a Baseline Assessment and Gap Analysis}

Through a baseline assessment, sites can identify and document the current infrastructure and activities in place that help integrate SD into facility design projects. Each of the parameters in Chapters 3 and 4 of this Roadmap identifies a key area where SD can be integrated into site operations (see Fig. 3). The baseline assessment will help determine how the site is addressing each of these parameters.

Once the baseline assessment has been completed, a gap analysis can be performed to identify the most important areas where the sites can incorporate SD. A gap analysis is a formal or informal means of comparing a site's activities, projects, and programs that facilitate integration of SD with the parameters identified in this document. The gap analysis documents current site activities and procedures that meet the intent of one or more of the SD integration parameters and identifies areas where additional steps are necessary to incorporate SD principles. 
Example: Each site's baseline assessment and gap analysis will be unique according to its needs. An example can be seen in the thorough baseline assessment and gap analysis performed by Argonne National Laboratory in 1998. A copy of their gap analysis can be viewed at http://www.pnl.gov/doesustainabledesign/.

\subsection{Establish SD Integration Goals}

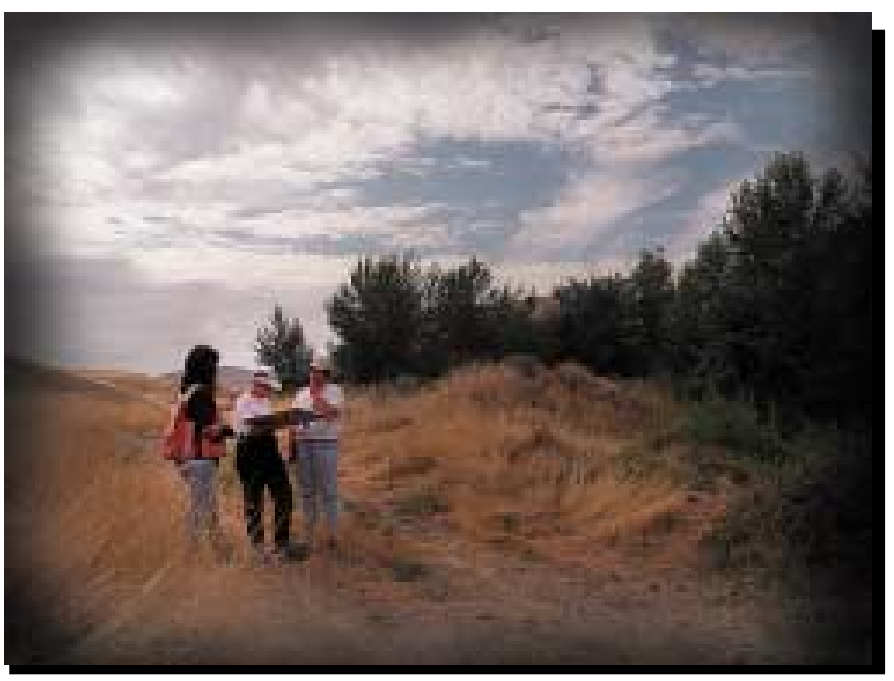

The gap analysis can be used as the basis for setting integration goals. Where the gap analysis shows that current activities are addressing the intent of SD integration parameters, no action may be needed. Where there is not sufficient activity to address certain parameters, the site can direct resources to meet that need. SD integration goals need not be elaborate, but they should include the following attributes:

- specific and measurable

- documentable

- supported by management and commitment.

\subsection{Follow an Action Plan}

Once SD integration goals are identified, an action plan can be used to ensure they are met. Many "templates" for action plans are available. The level of detail included in an action plan should be appropriate for the size of the activity. Often, action plans are informal, but to be most effective they should:

- be objective-driven rather than procedure-driven

- have an implementation schedule and interim milestones

- identify time and resource needs.

References: Argonne National Laboratory has completed an action plan for SD integration based on their gap analysis. A copy of ANL's action plan can be obtained by request from ktrychta@anl.gov. 


\subsection{Conduct Annual SD Performance and Test Reviews}

Self-assessments are an effective method of demonstrating progress on DOE goals and performance agreements across the complex. It is recommended that the sites perform selfassessments of their SD action plans and implementation progress on an annual basis, using the parameters from the Roadmap as a guide. Part of the review should include a check for updates in DOE policy and guidance for complex-wide deployment of SD into facility design. These reviews can confirm whether an integration strategy meets the intent of the DOE P2/E2 goals for SD, as well as demonstrate progress in addressing the priorities identified in a baseline review and gap analysis.

Each site should select indicators to measure the success of its integration of SD into the facility design process. Good SD performance metrics will be useful both for internal management and to demonstrate compliance with applicable DOE expectations and Federal Executive Orders. These performance measures should be able to address both the level of institutional integration and the impact of the changes to the design process on a design project's performance, costs, and life cycle costs. The performance metrics should give credit for site activities in place that meet the intent of SD integration as well as measure progress toward meeting site-established SD integration goals.

References: The FY 1999-2000 Energy Management Performance Agreements contain sustainable design performance measures. A draft performance expectation is provided in Appendix B, and sites can use it as a basis to evaluate performance. 
Particular attention must be directed toward demonstrating cost savings through environmentally sound design.

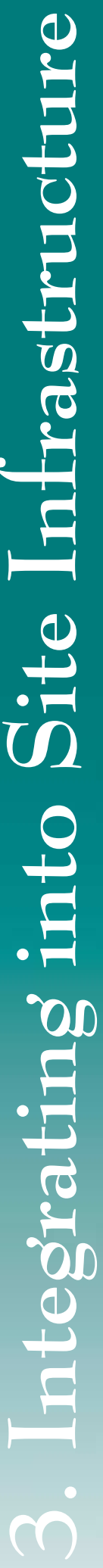




\section{Integrating Sustainable Design into Site Infrastructure}

Sites can systematically integrate SD into their facility design activities by following the program management strategy outlined in Chapter 2. There are two levels of facility design program management where SD can be integrated:

1. at the site infrastructure level, which covers the administrative systems and operations required to perform facility design projects

2. at the design project level, where the specific design elements are defined for individual facility projects.

This chapter discusses the site infrastructure level. Project-level integration is discussed in Chapter 4. By integrating SD into the site-level administrative systems, sites can facilitate broad systemic adoption of SD principles by their facilities and operations. Five areas of opportunity, or SD integration parameters, have been identified at the site infrastructure level:

- Policy

- Site Contractor Performance Agreements

- Site Operating Procedures

- Training

- Architecture and Engineering Standards of Specifications.

In this chapter, each parameter is described and a practical approach suggested for meeting the intent of the parameter. Then, as available and appropriate, examples and relevant references are cited to demonstrate the parameter. Wherever possible, references are provided along with Internet addresses for easy access. Full reference citations are given in Appendix A.

\subsection{Integrate SD into Site Environmental Policy}

Visible management support and commitment is vital to ensuring that pollution prevention measures are successfully integrated into the design of new buildings, renovations, and processes at the site. The site environmental policy statement is the most evident demonstration of such management commitment. This policy should be reviewed to ensure it encourages integration of SD principles into facility design projects.

Approach: The form and structure of an SD policy should be tailored to the management culture of each Operations Office. In most cases the SD policy can be integrated into the 
environmental policy, but in some instances, a specific policy statement for a site may be more appropriate. In either case, the reference to SD should be specific enough to:

- drive the implementation of SD into facility design and the continuous improvement in incorporating SD principles

- address application in all major DOE facility design projects

- contain specific objectives that can be clearly understood by internal and external parties

- contain a commitment to revise and update the policy as conditions warrant.

Example: Some sample language is offered below. Sites also may reference the DOE and Federal drivers for SD in their policy statement.

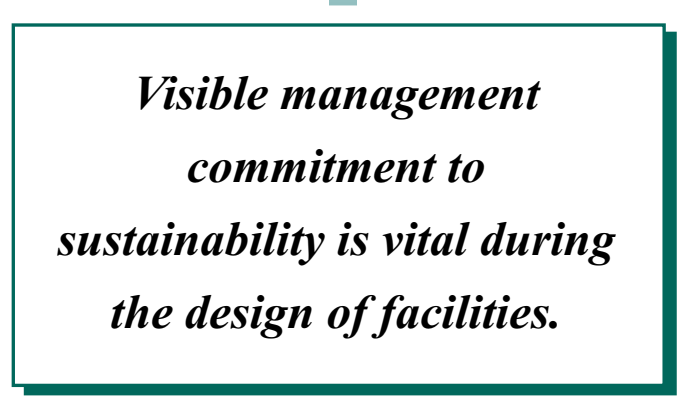

[This site] will demonstrate a sustained and integrated commitment to conserving resources and minimizing waste and pollutants during all phases of planning and implementation of all design projects.

Sustainable design shall be incorporated as a core value of site facility design and will be incorporated into all contracts, negotiations, and activities.

The tenets of sustainable design, resource conservation, energy efficiency, pollution prevention, waste minimization, reduction, and elimination shall be incorporated in all aspects of [this site's] facility design process and shall be developed as a core competency within facility design organizations.

References: The February 1999 Secretarial Memorandum and Executive Order 13123, attached in Appendix B, can be consulted to help frame site-level policy.

\subsection{Ensure SD Performance Agreements Are Integrated into Site Contractor Requirements}

DOE Headquarters has reference to SD in P2/E2 performance agreements currently in place for most Operations Offices. Site contractors carry out much of the actual implementation of these performance agreements. The Operations Offices communicate their expectations to the site contractors through performance agreements or operating contracts. The Operations Offices should ensure that site contractors have the appropriate provisions in their operating contracts and performance agreements to guide integration of SD into facilities and operations without conflicting with other contract provisions.

Approach: Site contractor operation contracts and performance agreements should be reviewed to ensure they will allow compliance with the SD policy (see Section 3.1), with the P2/E2 performance agreements, and with DOE 430.1, 430.2, and the applicable Executive Orders. Performance measures within the agreements should be revised annually to ensure that they remain a high priority. DOE project management personnel can use the contract language, performance agreement expectations, and SD principles when reviewing 
site contractor facility designs and should maintain good communication with the contractor on the importance of including SD into facility design.

Examples: Savannah River and Hanford have established SD performance measures for general application into site contractors' facility design projects.

References: The 1999-2000 P2/E2 Performance Agreement and performance expectations related to SD are attached in Appendix B.

\subsection{Revise Site Operating Procedures to Promote SD}

In addition to the performance agreements and contracts, each site maintains operating procedures and manuals. Site-level procedures are the most influential driver of institutional change. Each site should review and revise all appropriate procedures to specify integration of SD practices into facility design. The most critical procedure manuals to revise are those controlling facility design and pollution prevention policy.

Approach: To successfully integrate pollution prevention into site procedures, the following three steps are recommended:

1. Identify the appropriate procedures for revision. Typically, each site will have its own procedure manuals.

They should identify which of these manuals will best support integration of each of the SD integration parameters identified in this Roadmap. The manual governing engineering and technical design may be the best place to integrate the elements in Chapter 4, for example, and the manual on compliance and training may best house the parameters in this chapter.

2. Review selected procedure manuals to determine if they already have sufficient guidance to ensure incorporation of the Roadmap parameters.

3. Select a strategy for revising the procedure manuals. One method is to add specific language to each manual on how to perform SD in all aspects of the facility design process. This method is best for sites that want to ensure control over the method of integrating SD principles. However, it can be costly or difficult to secure approval, and will likely become obsolete as new complex-wide guidance and Federal drivers are established.

Another method is to revise the procedures to reference the applicable DOE orders and environmental policy. This approach may be best employed when there are budget constraints for procedure revisions; this approach also has the benefit of not needing to be updated with changes in complex-wide policy and guidance. 
This latter method of procedure revision presumes that DOE Headquarters-controlled procedures and guidance already have incorporated SD. This will not always be the case. In the interim, this Roadmap is established as a DOE Guidance Manual, and can be cited in site-level procedure manuals. Also, Appendix A identifies DOE-FM documents and Good Practice Guides that address various aspects of this Roadmap.

Example: In FY 1998, the Savannah River Site revised its procedures to include SD into facility design, and revised its E7 Manual: Conduct of Engineering and Technical Support. Within the manual a procedure, Pollution Prevention in Design, was added, and three procedures were revised:

- Conceptual Design Process Overview

- Plant Modification Traveler

- Task Requirements and Criteria.

\subsection{Provide Site-Level SD Training}

Adequate training is essential for incorporating SD at the site level. Training should be available for DOE and contractor project managers and facility design staff of basic SD, pollution prevention, energy efficiency, and Design for Environment (DfE) concepts. The training should also cover the DOE strategy and examples for integrating these concepts into facility design.

Approach: Sites should create training programs that focus on SD as part of accomplishing their mission and associated activities. Also, DOE has developed SD training and deployed both site-level and project-level training since 1995. Site training offices may reference the material in the DOE SD training packages or can arrange for customized training. Outside the DOE, other DfE training manuals are available that could be incorporated into site training programs.

Adequate training is essential for incorporating Sustainable Design.
Example: Three sites (Savannah River, Argonne National Laboratory-E, and Idaho National Engineering and Environmental Laboratory) received training on site-level integration of SD in FY 1998. Across the complex, over 19 facility design projects have received project-level training in the last 5 years.

References: Information on how to receive the DOE SD training is available at http://www.pnl.gov/doesustainabledesign/.

Two other DfE training references are ECODESIGN, an approach manual prepared by the Delft University of Technology, the Netherlands, and the Green Building Technical Manual, available at http://www.sustainable.doe.gov/. Further DfE resources that may be useful for preparing training are listed in Appendix A. 


\subsection{Revise Applicable Architecture and Engineering Standards and Specifications}

Engineers use Architecture and Engineering (A/E) standards and material specifications during project definitive design to provide a baseline for costing the design. A/E standards typically span the spectrum of engineering disciplines and provide guidance on such areas as reference codes, company design policy, documented agreements with regulators, and materials or items precluded from use. Each site should review and update its contractors' $\mathrm{A} / \mathrm{E}$ standards and material specifications to preferentially select resource and energy conservative materials and practices. The $\mathrm{A} / \mathrm{E}$ standards should be updated to promote compliance with Executive Orders 13101 and 13123.

Approach: While it might be useful to develop uniform $\mathrm{A} / \mathrm{E}$ standards across the DOE complex to ensure SD language and philosophies are incorporated throughout, complex-wide agreement to a uniform standard may be difficult to establish. Moreover, such uniform standards would often come in conflict with local standards. Consequently, sites are encouraged to use Green Building reference catalogues and databases to identify resource and energy efficient building materials and design elements to incorporate into their $\mathrm{A} / \mathrm{E}$ standards and specifications.

Examples: Oak Ridge National Laboratory performed an extensive review of their Central Engineering Services Command Media and identified over 130 potential changes that could be incorporated in the technical specifications and engineering standards to promote SD. The result was that 43 specific changes were made in the command media to address recycled content procurement and process design opportunities.

References: More information about the technical specification revisions made at Oak Ridge is available at http://engineering.ornl.gov/projects/p2d/. Furthermore, three reference tools are particularly useful because they are organized by engineering discipline:

- Greening Federal Facilities

- The DOE P2-EDGE software

- Green Spec.

More information on these and other A/E reference tools is included in Appendix A. 
A facility's environmental performance should be viewed from a "whole building" perspective over its life cycle. 


\section{Sustainable Design Implementation}

at the Project Level

Chapter 3 addressed the need for SD in the broad site-level infrastructure for successful adoption of SD principles. This chapter focuses on the various ways facility design projects can integrate SD. Project-level integration of SD is essential for effective site-wide integration because that is when actual SD principles are implemented. The motivations and potential benefits for integrating SD into a project are listed below:

- lower project life cycle cost

- reduced waste generation both during construction and during operation of the facility

- improved energy efficiency, effective material acquisitions, and increased resource conservation during construction and operation of the facility

- fewer regulatory requirements

- improved public perception

- improved health and safety of facility occupants.

Ten project-level SD integration parameters are identified in this chapter. These parameters are listed in Fig. 4 and are briefly described in Section 4.1. Not all 10 parameters will apply to all projects. Section 4.2 suggests a graded approach for identifying which parameters apply to an individual project. Sections 4.3 through 4.5 offer further guidance on some of the parameters. Section 4.6 provides a checklist for identifying the relevant projectlevel integration parameters and for tracking progress during design activities.

\subsection{Project Level Integration Parameters}

\section{Figure 4. Project-Level Integration Parameters}

1. Project Charter

2. Budget Planniang

3. Project Team Leadership

a. Assign Sustainable Design integration lead/point of contact

b. Identify Sustainable Design integration team

4. Training

5. Conceptual Design Documentation

6. Integration with Existing Project Design Processes a. Into Value Engineering studies b. Into NEPA documentation

7. Project Cost Baselines a. During Conceptual Design

b. Revise cost baselines to include SD opportunity LCC savings

8. Pollution Prevention Design Assessment

a. Quantify waste and material streams

b. Identify opportunities to eliminate, reduce, reuse, or recycle

c. Evaluate feasibility and cost/benefits of opportunities d. Implement selected opportunities

9. Architecture and Engineering Subcontracts a. Integrate into Design/Build contracts

b. Incorporate into construction planning and methods

10. Facility Operations and Decommissioning

a. Verify implementation of design opportunities

b. Create Operations SD plan or manual

c. Incorporate SD into Decontamination \& Decommissioning Plan

One of the ways that sites can demonstrate progress of SD integration is by tracking how the individual projects are applying SD principles (see Sections 2.4 and 3.2 for further discussion of measuring performance). The 10 project-level activities (shown in Fig. 4) are specific steps for effectively performing SD over the course of a project. The parameters are sorted generally according to when they can be adopted during the project design 
process, with the more conceptual planning parameters listed first. The parameters that identify specific opportunities for adopting SD principles are best applied in the definitive design and construction phases of the design project.

\section{Incorporate SD into project charter}

The types of project planning documents will vary, depending on the complexity of the project. Most projects, however, provide documentation of the purpose and scope of the design project. At this very initial step, a project can propose to apply SD principles. Such a project charter will be a driver and support for adopting SD into every subsequent phase of the project.

\section{Include SD into project budget planning}

Inadequate funding is the single greatest barrier to incorporating SD. In the initial phases of project planning, it is vital that the budget plan include funding to support review of resource consumption and environmental impacts of the project, along with an evaluation of the SD integration opportunities that can avoid these

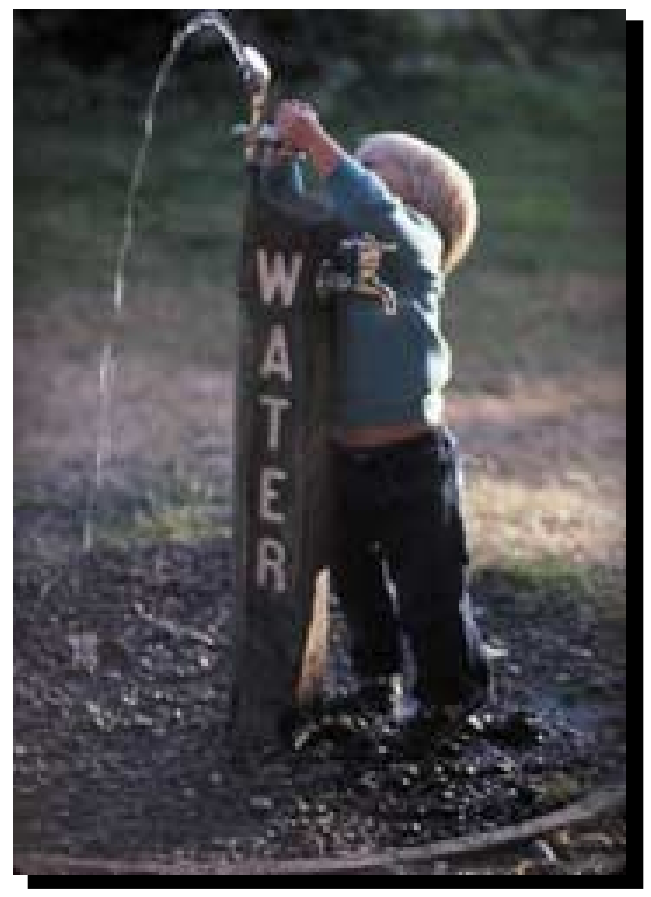
impacts. The project budget should also be sufficient to apply the other SD project-level integration parameters. The level of integration of these parameters, and the related funding requirements, will vary, depending on the design project's size and scope. Section 4.2 provides guidance on how to grade the level of parameter application that is appropriate for individual design projects.

\section{Establish SD team leadership for the project}

The design project team is generally identified and selected early. A SD integration team will be responsible for ensuring the appropriate SD activities. The SD team's size will also depend on the size of the project.

\section{3a. Assign SD integration lead/point of contact.}

All projects should assign a SD integration point of contact, who should have pollution prevention and energy efficiency training, as well as an understanding of SD principles. In some cases, the design project team leader will act as the SD point of contact. For small projects, a SD point of contact alone may be sufficient to ensure SD principles are integrated into the project.

\section{3b. Identify SD integration team}

For smaller design projects, the SD integration team may coincide with the design team. For larger projects, the SD team will be some subset of the design team, but it should have a technical representative from each of the project's applicable design disciplines. The following qualities should be considered when selecting team members:

- upper management support

- customer buy-in

- diverse and knowledgeable team members

- training in pollution prevention and energy efficiency, and in SD principles 
- comprehensive process knowledge

- representation from a similar operating facility

- waste management, regulatory compliance, and safety

- cost estimating expertise

- research and development support.

Fig. 5 offers a matrix of potential SD integration team members and their roles.

\section{Figure 5. SD Integration Team}

\begin{tabular}{|c|c|}
\hline Job Function & Potential Contribution to Sustainable Design Integration \\
\hline Customer & $\begin{array}{l}\text { Authorize added design cost for SD integration in order to lower total project cost; } \\
\text { provide information about needs and environmental preferences; offer feedback on } \\
\text { design alternatives. }\end{array}$ \\
\hline Project Management & $\begin{array}{l}\text { Establish SD team; establish project's environmental policy; set goals and establish } \\
\text { measures for success; develop environmental strategy. }\end{array}$ \\
\hline $\begin{array}{l}\text { Sustainable Design } \\
\text { subject matter contact }\end{array}$ & $\begin{array}{l}\text { Provide overall guidance to the team on Sustainable Design principles, techniques, and } \\
\text { practices. Communicate the project's SD successes to the regulators and the public. }\end{array}$ \\
\hline R\&D staff & Develop and transition innovative technologies for source reduction. \\
\hline Designers & $\begin{array}{l}\text { Create a design concept that meets environmental criteria while still satisfying all other } \\
\text { important functions. }\end{array}$ \\
\hline Process engineers & Design processes to limit resource inputs and pollutant outputs. \\
\hline Cost estimators & Assign environmental costs to products; calculate hidden, liability, and less tangible costs. \\
\hline Procurement & $\begin{array}{l}\text { Give designers feedback on existing products and demand for alternatives, including } \\
\text { recycled content and low toxicity products; select suppliers with demonstrated low-impact } \\
\text { operations; assist suppliers in reducing impacts of their operations to ensure steady supply } \\
\text { at lower costs. }\end{array}$ \\
\hline Industrial Hygiene/Safety & $\begin{array}{l}\text { Inform designers of added costs such as protective equipment, ventilation, and air } \\
\text { monitoring associated with product application during construction; provide environmen- } \\
\text { tal information on selected products; assist with comparing material choices for environ- } \\
\text { mental impact. }\end{array}$ \\
\hline Regulatory compliance/ permitting & $\begin{array}{l}\text { Interpret Executive Orders, DOE policy, and regulatory statutes and promote SD to } \\
\text { minimize cost of regulation and possible future liability. }\end{array}$ \\
\hline Waste Management professionals & $\begin{array}{l}\text { Offer information about the fate of industrial waste and retired consumer products and } \\
\text { options for improved practices. }\end{array}$ \\
\hline Risk Assessment & $\begin{array}{l}\text { Safety Analysis Report includes estimates of offsite doses that require estimates for } \\
\text { emissions. Therefore, some quantification of waste streams during design is necessary } \\
\text { regardless of whether SD is integrated. This information should be shared between the } \\
\text { Safety Analysis Report authors and the SD team. }\end{array}$ \\
\hline
\end{tabular}




\section{Provide SD training for project}

The SD team should receive training on SD principles and how to apply them to the project. DOE offers a SD integration course for design projects (see Section 3.4), and numerous DfE courses are available through the private sector. In some cases, the training can be conducted as a workshop where the outcome can provide certain elements of SD integration into the project, such as identifying opportunities for SD application.

\section{Document SD opportunity application into Conceptual Design Report}

The objectives of the conceptual design phase of design projects are to develop a project scope, ensure project feasibility and attainable performance levels, identify project risks, and develop a cost estimate and schedule. This is a critical time to begin incorporating SD principles into the design project, because nearly all the general construction and operation design elements are defined during concep-

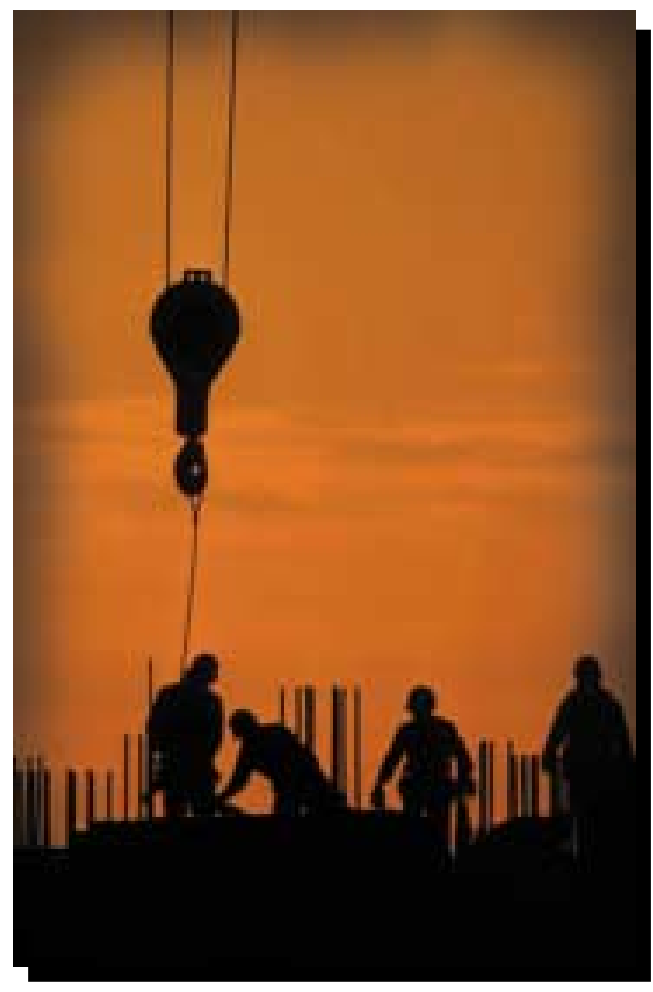
tual design. Risk assessments, waste assessments, life cycle cost estimates, process performance criteria, and water and energy use estimates are first performed and documented during conceptual design. High-level SD principles (such as those defined in Section 1.2) can be called out and incorporated into the Conceptual Design Report (CDR). The SD opportunities identified in this phase will not be as quantitative as in subsequent stages, but the potential impact of the opportunities are much greater because the design is less defined and more flexible at this phase. Also, by documenting the opportunities in the CDR, the project will have a strong driver to promote detailed $\mathrm{SD}$ integration during the later phases of the project.

\section{Use existing project design processes to adopt SD principles} Many of the project management processes already in place at DOE have elements that complement sustainable design. Value Engineering (VE), Environmental Management (e.g., ISO 14001) systems, Environmentally Preferrable Purchasing (Affirmative Procurement) requirements, and National Environmental Policy Act (NEPA) reviews are a few examples of complementing design processes that can be used to meet the intent of some aspects of SD. Value Engineering and NEPA documentaion merit special consideration because of their prevalent use in design projects:

\section{6a. Application of Value Engineering}

Value Engineering, like SD, is a project management methodology intended to be absorbed into all elements of the design process. VE is incorporated in a project to improve efficiency and cost-effectiveness when analyzing physical asset acquisition; SD simply provides an additional environmental focus on these objectives. Most of the SD project-level integration parameters can be deployed using VE practices. Further information about VE is available in the Life Cycle Asset Management Good Practice Guide, GPG-FM-011, and can be downloaded from http://www.fm.doe.gov/FM-20/guides.htm. 


\section{6b. Application of NEPA documentation}

All design projects are generally required to perform an environmental evaluation in accordance with NEPA. The goal of NEPA is to identify any alternative (e.g., pollution prevention; recycling; control) that will reduce environmental impacts of the design project. There are NEPA checklists that can act as excellent templates for reviewing the associated wastes and resource demands of the project and for suggesting environmentally preferred alternatives. The NEPA process complements several SD integration steps, and is particularly useful when performing a Pollution Prevention Design Assessment (described in project-level parameter 8). Some smaller projects have found that just by considering SD opportunities during their NEPA evaluation they have significantly improved the $\mathrm{SD}$ elements of the project. A very good source of information for integrating pollution prevention during NEPA documentation is available from DOE-RL Pollution Prevention Program at http://apsq105.rl.gov/polprev/nepa/nepa.htm.

\section{Include SD cost/benefits into project cost baselines}

As when budgeting the costs of performing SD integration activities (parameter 2), it is critical that SD integration costs and benefits be included into the project cost baselines. The potential opportunity costs of integrating specific SD principles into the project design must be recognized.

It is important to incorporate SD into the project baselines when:

\section{7a. preparing the Total Estimated (project) Cost (TEC) and Life Cycle Cost baselines during the Conceptual Design phase.}

7b. updating project cost baselines during Baseline Reviews in later design phases.

Section 4.3 provides more guidance on incorporating SD into project cost baselines.

\section{Perform a Pollution Prevention Design Assessment}

The DOE has established a method for systematically identifying and implementing pollution prevention and energy efficiency opportunities during the design phases of projects. The method is called the Pollution Prevention Design Assessment (P2DA) and is a variation of DOE's original Pollution Prevention Opportunity Assessment (PPOA). The distinction of the P2DA is that it is performed before projects are operational, and thus forecasts waste-generating and energy-consuming processes and activities, and identifies environmentally preferred alternatives during design.

The basic framework of the P2DA process consists of four steps:

8a. Quantify waste and material streams.

$\mathbf{8 b}$. Identify opportunities to eliminate, reduce, reuse, or recycle.

8c. Evaluate feasibility and cost/benefits of opportunities.

8d. Implement selected opportunities.

"A well-defined problem is half solved" is particularly true for the $P 2 D A$ process. 
The P2DA process is described in greater detail in Section 4.4.

\section{Include SD expectations in architecture/engineering, and construction subcontracts}

Another important opportunity to integrate SD is when hiring A/E and Construction contractors. The design project should include SD requirements in the design and construction bid request packages to ensure the subcontractors implement the SD opportunities that have been identified during earlier phases of the design.

\section{9a. Integrate into design/build contracts}

Environmental performance-based fee awards could be included in the design and construction contracts. Such awards give a positive incentive for contractors to implement SD into the facility design and construction. More details about performance incentive contracting are given in Section 4.5.

\section{9b. Incorporate into construction planning and methods}

The SD opportunities during the construction phase of design projects are often overlooked. Construction by its nature presents a difficult challenge in controlling costs and preventing waste and error. Recycling and reuse methods, for example, should be in place to control construction debris. It has been estimated that for a typical office building, the amount of waste generated during construction is approximately equivalent to the amount of waste generated over the entire first decade of operating the office building. Finding sustainable alternatives to this waste generation is important.

\section{Ensure application of SD principles into facility operations} and decommissioning

Many of the benefits of SD integration opportunities will not be realized during the design and construction phases of the project. By nature, SD has its greatest impacts on resource conservation, waste avoidance, and energy efficiency during the operation and decommissioning phases of a project's entire life cycle. For this reason it is important that the design project takes measures to ensure that the good SD opportunities can be realized after the design phase is completed. Three methods are recommended:

\section{0a. Verify implementation of design opportunities}

A final review of the status of the SD implementation should be made before the design project closeout. In particular, during procedure, facility, and equipment acceptance testing, the test procedures should measure and assess waste generation and energy consumption of the final project or process. The objective is to ensure that the SD principles incorporated into the project achieve their expected waste avoidance, resource efficiencies, and cost projections.

\section{0b. Create an operations SD plan or manual}

A special "owner's manual" that describes the purpose, functioning, and maintenance procedures for the SD features of the completed project can be useful to optimize the benefits of these features. Often, successful realization of the implemented SD principles depends on the how they are utilized during operations. For example, certain energy efficiency measures would be reduced if special equipment maintenance procedures were not followed. The SD principles that have been implemented 
into the project often require different operating and maintenance practices than what was used historically. All of these special conditions can be addressed in the operations plan or manual, and can be provided to the operations managers.

\section{0c. Incorporate SD into decontamination \& decommissioning (D\&D) plan}

An effective design project should account for what to do when the useful operations of the facility or process are complete. Preparing a D\&D plan can help prevent unexpected and severe legacy waste issues, which would nullify the positive benefits and cost savings designed into the construction and operation phases. The D\&D plan can address disassembly and contamination issues, alternate uses for the facility or site, resource and material recovery, and recycling options.

\subsection{Graded Level of Implementation}

Projects should consider a graded approach to integrating SD within the design project. The level of integration of SD into the project, and the extent of application of the 10 projectlevel integration parameters, should be commensurate with the expected degree of waste generation and resource consumption throughout the life of the project. The level of application should also be appropriate for the size, scope, and cost of the design project. If a graded approach is properly applied, the resulting cost savings throughout the life of the facility should pay back any expense of implementing SD principles during design. A project-level grading methodology is suggested here and is incorporated into the Project-Level Integration Checklist described in Section 4.6. The grading methodology addresses three aspects of the design project:

- cost of the design project

- scope of the design project

- level of completion of the design project.

For the first two, to help ensure that the SD integra-

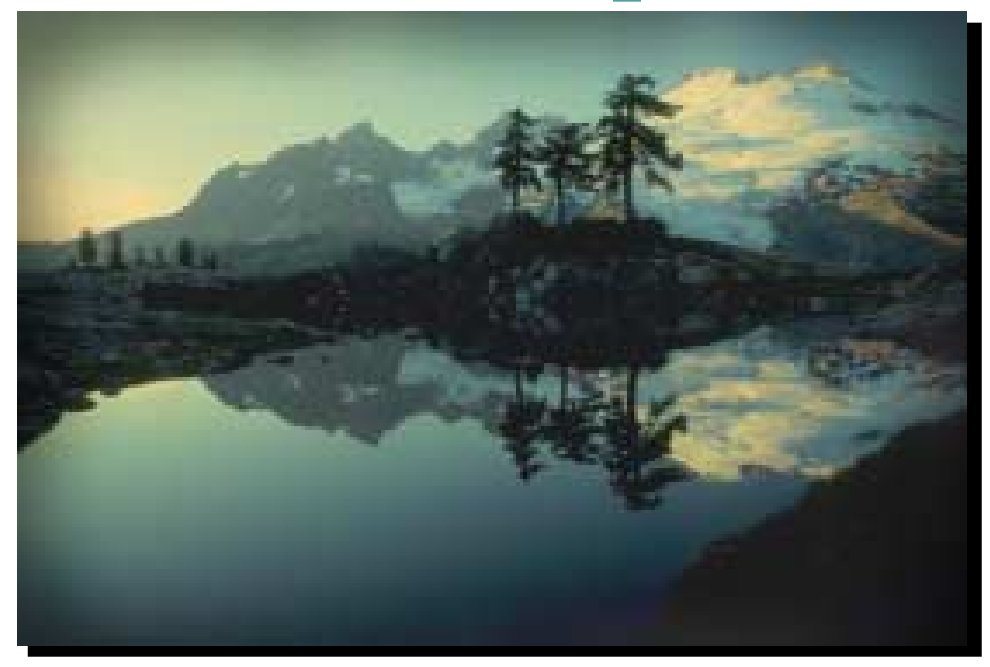
tion activities are commensurate with the size and scope of the project, priority ratings are assigned to the 10 project-level integration parameters. Ratings of Small (S), Medium (M), or Large (L) indicate which subset of the 10 tasks the projects are advised to complete based on size (cost) and scope. The Total Estimated Cost (TEC) of the project defines the cost portion of the grading methodology. The TEC ranges for each level will ultimately need to be decided by the sites as they integrate SD into the project design infrastructure. As an example, the cost ranges might be that Small projects are less than $\$ 300,000$ TEC, Medium projects are $\$ 300,000$ to $\$ 3,000,000$ TEC, and Large projects are greater than $\$ 3$ million TEC.

In addition to grading according to cost, the projects can be graded according to scope. For example if the project is critical for performing a site mission, it would be graded with a Medium rating; if the project is critical for completing a DOE mission or if it evaluates critical DOE mission options, it would be graded as a Large project. 
Large projects should incorporate all 10 of the project-level SD integration parameters into the design. Medium projects should address all items with a Medium priority rating (see the Project-level Integration Checklist in Section 4.6); and small projects should complete the items with a Small priority rating.

After grading the size and scope of the project, a second ranking should be applied based on the level of completion of the design project. Some of the project-level integration parameters can only be applied during specific phases of the design project. The ProjectLevel Integration Checklist indicates which design phase - conceptual, preliminary through definitive, construction, and project closeout - the specific parameters can be applied to. Projects beginning integration of SD principles during later phases of design would be exempted from addressing those parameters that apply to early design phases.

Again, these project-level grades are for guidance, and are not prescriptive for uniform application for all projects at all sites. It is recommended that each SD Integration Action Plan (see Section 2.3) build a site-specific consensus of what individual projects will achieve, depending on size, scope, and phase of completion in

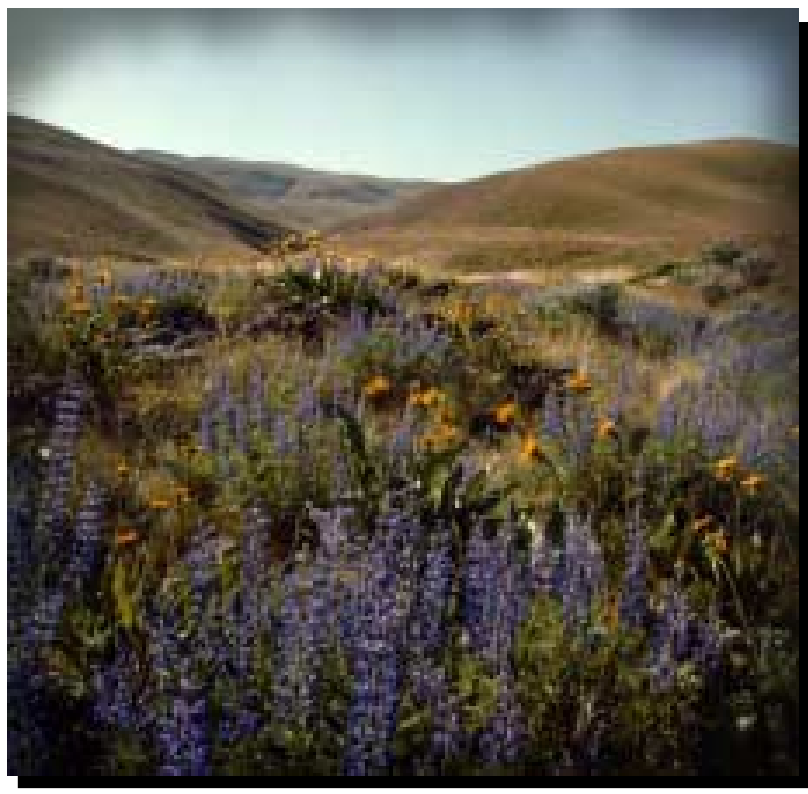
order to meet the intent of SD integration.

\subsection{Integration into Project Cost Baselines}

For successful long-term implementation of SD into individual design projects, particular attention must be made in demonstrating the cost savings through environmentally sound design. As projects identify environmental design opportunities, they should track how the design changes influence the TEC through construction and the Life Cycle Cost (LCC), which includes the facility's operations, maintenance, and decommissioning costs.

For a design project to gain approval to proceed beyond conceptual design, a LCC is calculated, but often with two shortcomings:

1. It is incomplete for use as a baseline for incorporating many SD principles unless all the waste and resource costs of a facility are considered.

2. A decision-making connection is needed between the LCC baseline and the design project deliverables. This connection is important if SD opportunities are identified that may significantly reduce the LCC but at the consequence of raising the design and construction phase costs (TEC). In such cases, opportunities may be dismissed prematurely.

For LCC reductions to be realized, design projects need an additional measure of success, besides meeting TEC and schedule. Design projects should also be measured on their ability to design in operational and decommissioning cost savings, and be given some flexibility in managing the TEC to allow incorporating LCC saving strategies. Design projects 
can facilitate gaining this flexibility by improving the utility of the LCC and TEC baselines to include SD integration as part of the project decision process, as illustrated below.

Integrate SD metrics into LCC and TEC baselines: DOE has typically required that projects establish project cost baselines at $2 \%$ to $5 \%$ of project design completion, while other Federal agencies and the private sector would commonly develop a cost baseline at approximately $35 \%$ of design. This early establishment of cost baselines poses some significant barriers to SD integration.

First, when baseline cost is fixed at the conceptual design phase, the scope of a project is only understood at a very high level of generality, making it difficult to consider the viability of specific SD opportunities.

Second, the cost baseline upon which design scope decisions are based is not a full LCC of the project. It only reflects costs incurred through facility commissioning, but does not include operation and decommissioning costs. This is important from the SD perspective, because the most attractive SD options often realize their benefits primarily in the operation and decommissioning phases of a facilities life cycle, while costs are typically incurred in the design, construction, and commissioning phases.

The result of the early locking-in of baseline cost (TEC) is the early locking-out of SD options that may provide significant LCC benefits from a modest up-front investment. If a baseline cost is already established, it is very difficult to argue for increasing up-front cost for any reason, even if long-term cost savings are projected. It is institutionally much easier to grant SD options a fair evaluation before cost baselines are established (and difficult to increase).

All of this emphasizes the importance of including SD elements into the cost estimates when the project baselines are being established. The primary DOE source of information on incorporating environmental considerations into baseline TEC and LCC costs is the Pollution Prevention by Design Project Cost Estimating Guide, available at http://www.pnl.gov/doesustainabledesign/.

Document SD opportunity costs and benefits when performing LCC and TEC baseline reviews: Most SD features create LCC benefits; these should be calculated and documented during the P2DA (project-level parameter 8). During baseline reviews, the TEC and LCC baseline should be readjusted to reflect the impacts of the selected SD opportunities. With good documentation, this should help gain approval for project scope changes when they are necessary to maximize the long-term, life cycle benefits of the SD integration.

Reference: EPA has developed a software program to assist in capturing and calculating life cycle costs. For more information about this software, called P2/Finance, see the EPA's Enviro\$ense website at http://es.epa.gov/techinfo/finance/finance2/html. 


\subsection{The Pollution Prevention Design Assessment}

The P2DA provides a structured methodology that can be applied during any phase fromconceptual to definitive design - and provide the project team with specific design suggestions that could cost-effectively minimize waste generation or environmental impact over the life of the facility. The basic framework for the P2DA process is depicted in Fig. 6.

Step 1-Quantify Anticipated Waste Streams and Resource Consumption: “A welldefined problem is half solved" is particularly true for the P2DA process. In the process of identifying streams and their origin, ideas for eliminating or minimizing those streams often surface. This step of the P2DA is the most critical because it will provide the data to determine the strategy to proceed. Data on waste generation will be

Figure 6. The Process Steps of a Pollution Prevention Design Assessment

\section{Step 1-Quantify Waste and Material Streams}

- Identify anticipated streams (construction, operations, closure/dismantlement)

- Q uantify streams: source (unit operation/activity), regulatory status, expected frequency/duration/volume, unit cost, total cost.

\section{Step 2-Identify Design Opportunities}

- Brainstorming techniques

- Benchmarking successful techniques/lessons learned

- Establishing design strategies

\section{Step 3-Evaluate Feasibility and Cost/Benefit of SD Alternatives}

- Cost analysis

- Environmental analysis

- Select SD opportunities to implement

\section{Step 4-Implement Selected SD Opportunities}

- Implement selected SD opportunities into design

- Measure progress/reevaluate goals

- Document SD integration in Project Summary Report used to prioritize streams and define the scope of the remainder of the P2DA. The time spent on the remainder of the P2DA should be allocated appropriate to the priority of the stream.

Also note that because SD principles include resource conservation and reduced use of hazardous materials, the P2DA should not be limited to identifying waste streams, but should also include identifying energy-and resourceintensive processes.

\section{Identify Anticipated Waste and} Material Streams: Identifying anticipated waste streams is more difficult for a P2DA than for a PPOA process where the process physically exists and is operating. To identify anticipated waste streams during design, project members need to consider wastes that will be generated during construction, operations, and closure/dismantlement of the facility. Pollution prevention is a multimedia approach that requires examination of air emissions, liquid wastes, and solid wastes.

Furthermore, wastes are not just generated by the primary facility processes, but by support functions (e.g., utilities) and facility maintenance. Finally, waste stream identification requires an examination of not only routine continuous and batch processes, but nonroutine processes should be examined as well. 
Quantify Anticipated Waste Streams: Gathering the data to quantify waste streams that will be generated is more difficult than quantifying existing processes because the physical system does not exist yet. Direct measurement is impossible, and plant records or other historical data are nonexistent. Therefore, estimates need to be drawn from vendor data or preliminary calculations used to size equipment. To some extent, waste generation may also be estimated based on the operating parameters established by the requirement documents for the project. Another technique is to look at a similar facility in operation, and project waste generation rates based on an extrapolation of the operating facility's waste/ production ratio.

Step 2 - Identify Sustainable Design Opportunities (SDOs): The next step is to identify specific design changes that would prevent or minimize the anticipated waste streams and avoid critical material, energy, or water consumption. One useful technique for identifying SDOs is to record, for each priority stream, whether that stream is non-useful (waste), recyclable, or a possible feed for another process within the facility. For example, gray water can possibly be used for irrigation rather than raw water. Organizing streams by non-useful, recyclable, or feed will help the project to identify SDOs. Opportunities are discovered by matching candidate processes to waste streams that are potential feeds, or by designing mechanisms to send recyclable streams back into the process or offsite. Non-useful streams should be eliminated or minimized at the source to the extent possible.
Typically, the amount of waste generated during construction of an office building is about the same as the amount generated the first decade of operation. Finding sustainable alternatives to this waste generation is important.

While brainstorming for additional SDOs, it is helpful to think of major categories of process and product improvements such as process substitution, process control, more efficient facility layout, inventory management, equipment modifications, production process modification, recycled content products, or spill prevention and control techniques. A related technique is to brainstorm ideas along a specific design strategy, such as design for recyclability, design for disassembly, design for eco-efficient materials management, design for durability, design for life extension, design for maintenance, design for energy conservation, design for water conservation, or design for hazardous materials reduction.

One other technique for identifying SDOs is to look at lessons learned from similar operating facilities. In these cases, the design needs to take care not to completely duplicate previous design efforts and yet foster a continuous improvement approach. For example, new designs should phase out products or processes from current operations with unacceptable environmental impacts but continue to use environmentally sound practices.

Step 3-Evaluate Feasibility and Cost/Benefits of Design Alternatives: In this step the project performs further evaluation of the identified SDOs to determine which ones can be implemented effectively into the design project. Some SDOs may need to be dropped because they are not feasible due to schedule constraints or technology limitations. Such qualitative evaluations will be subject to other design objectives of the project. 
The SDOs should also be subject to a cost/benefit evaluation. Some of the costs to consider include usual costs, hidden regulatory costs, and less tangible costs. Usual costs include capital (buildings and equipment) and operating expenses. Less tangible costs include such items as future liabilities and worker health benefits. Full cost accounting of design projects is complicated by the fact that the design detail is not fixed, and so neither is the cost. Guidance about cost calculation was more fully covered in Section 4.3.

The SDOs that should be selected for implementation are those that can be demonstrated as environmentally, technically, and logistically feasible, and where the cost/benefits, especially the life cycle cost/benefits, are improvements over the original or traditional design.

Step 4-Implement Selected Opportunities: At this point in the P2DA process, the team has identified the major waste and material streams, established the scope of the analysis depending on budget and schedule constraints, brainstormed SDOs within the boundaries of the P2DA scope, computed implementation cost and potential savings for the more promising SDO, and selected the SDOs that are cost effective or otherwise attractive for implementation. Now, the P2DA effort needs to be integrated into project records. This step includes 1) implementing design changes as a result of selected SDOs, and 2) communicating overall waste reduction successes to the customer, regulators, and other project stakeholders.

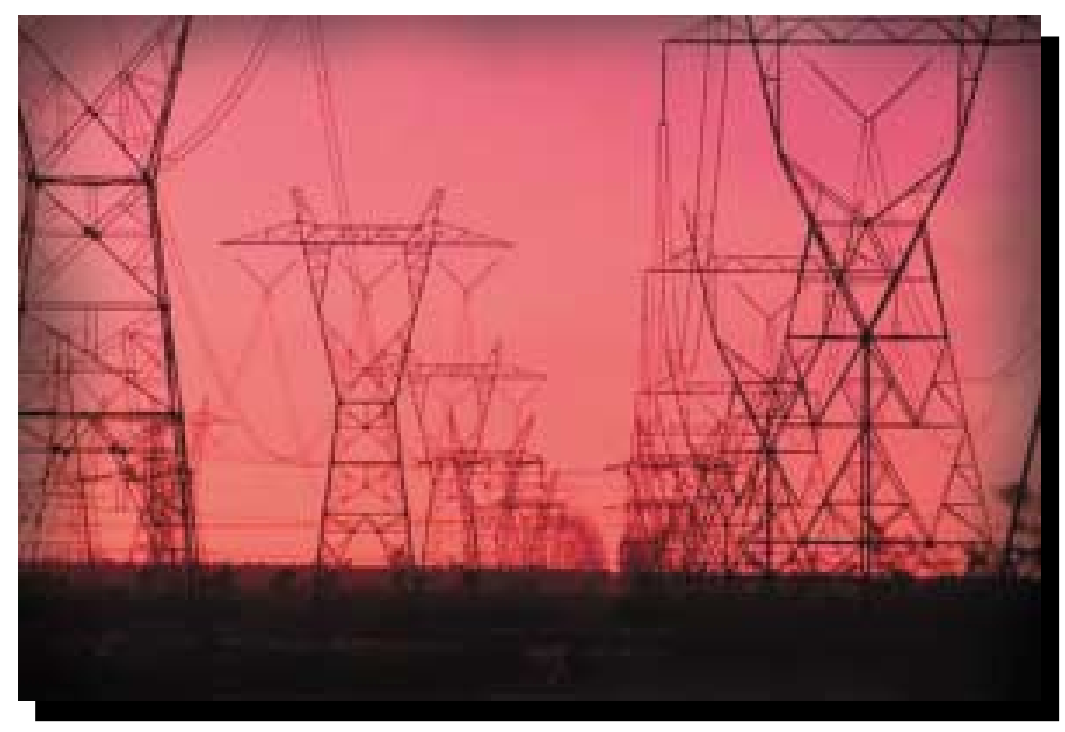

Depending on the design stage, it may be appropriate to include the cost evaluation worksheets for selected SDOs as formal calculations, assigning a calculation number so that it is officially tracked within the project management system. By doing so, the drawings, specifications, design reports, etc., that are impacted by SD implementation are clearly identified. Similarly, if inputs to the calculations change, then the SDO cost evaluation can be updated and reevaluated for cost effectiveness. Design changes as a result of selected SDOs need to be reflected on the impacted drawings or specifications, and clearly communicated to interfacing design disciplines.

The second objective of communicating overall results to stakeholders can be achieved either by adding text describing the overall P2DA effort and results directly into design reports, or, for more-detailed P2DAs, the approach and results can be submitted in a standalone report that can be attached as an appendix to the design reports or even permit applications.

Reference: The Waste Minimization/Pollution Prevention Good Practice Guide (GPGFM-025, available from the Internet at http://www.fm.doe.gov/FM-20/guides.htm), and the training packages referenced in parameter 4 offer greater detail, with worksheets and case studies on how to perform a P2DA. 


\subsection{Architecture and Engineering Subcontractor Incentives}

The common method used by design and construction contractors to price new projects is by the facility's "footprint," which is typically measured in square footage. Conventional compensation provides no reward for the extra effort required to include resource and energy efficiency. Moreover, the designers do not get any of the savings if they do design in such benefits. In fact, under many fee structures, the designers' profits actually fall because many efficient buildings need smaller and simpler mechanical systems for cooling, heating, and air handling, making the whole building cost less, and causing fees based on a percentage of construction cost to drop correspondingly.

When facility projects are soliciting bids for design and construction work, they have an opportunity to specify SD requirements, such as maximizing efficient energy use, minimizing water use, using recycled content construction materials (in accordance with Executive Order 13101), and considering compliance with existing energy codes to be only the minimum standard. Moreover, award contracts can be set up to allow the bidders to score higher based on their incorporation of SD measures and design elements. As DOE moves to "privatized" build/operation fixed-price contracts, one particular incentive is to base contractors' fees on the facility's SD performance. For example, contractors could be paid for the amount of energy savings, water conservation, and productivity efficiency that is designed into the facility above average industry or regional standards.

Contractors could be paid for the amount of energy savings, water conservation, and productivity efficiency designed into a facility.

Example: At Richland, Washington, the Applied Process Engineering Laboratory (APEL) used P2 by Design construction principles from the beginning of final design through its construction and startup in April 1998. The APEL project was a unique application of the process, because it was a teamed design and construction project, with DOE as one of the clients. As such, it was necessary to tailor the P2DA to allow for a "handing off" of the project design from DOE to a Design/Build contractor. This hand-off of the implementation responsibility was the impetus for an innovative incentive tool, the inclusion of SD performance measures as part of the contractor selection criteria. The main criteria were the quantity and quality of work delivered for a fixed price, but SD was weighted at 10 points out of 100 of the overall evaluation. The SD award points were as follows:

\section{Bid Award Points Criteria}

\section{Item}

Integration of $\mathrm{P} 2$ by Design Assessment Process

HVAC Energy Conservation

Electrical Energy Conservation

Building Envelope Energy Conservation

Use of Recycled Content Materials

Spill Protection for Floors
Award Points 
References: An article that discusses innovative contract incentives in greater detail is Green Fees: Getting Paid for Getting It Right. The article can be viewed at the Rocky Mountain Institute Internet site at http://www.rmi.org/gds/pbf/index.html.

Further details about the APEL project are available in the 1998 DOE Pollution Prevention Conference proceedings of the paper, "Pollution Prevention Incentives in Constructing a Regulatory Aligned Business Enterprise Center," by C.R. Allen and K.L. Peterson, available in the proceedings on the Internet at http://www.hanford.gov/polprev/conference/ index.htm.

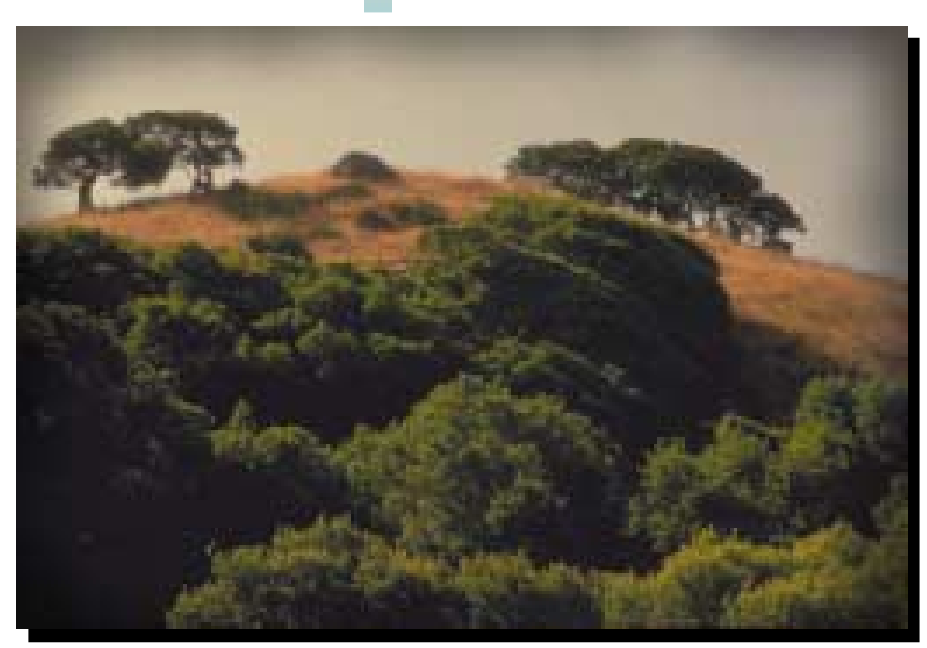

\subsection{Project-Level Integration Checklist}

There have been several aspects of project-level integration discussed in this chapter. A checklist methodology has been developed to help facilitate adopting SD at the project level. The checklist, shown in Fig. 7, identifies the specific activities that can be performed to address the 10 project-level SD integration parameters (as identified in Section 4.1). The checklist works as a template to grade the project according to size, scope, and project phase. Through the grading process, the project can identify which project-level integration parameters are recommended for application. Fig. 7 also provides instruction on how to identify the applicable integration parameters by using the Project Level Integration Checklist. 
Figure 7. The Project-Level Sustainable Design Integration Checklist

\section{Step 1.}

Grade Integration by Size and Scope Identify the size and scope, then track down the matrix to see which integration activities apply to your project. Cross out the parameter numbers that do not apply.

\section{Step 2.}

Grade Integration by Phase of Project Identify which design phase(s) the project is in, then track down the grid to see which SD integration activities identified in Step 1can be performed. Cross out the parameter numbers that do not apply (Note that if your project is in an early phase, some activities that do not apply now may apply in later phases).

\section{Step 3.}

\section{Identify the SD Integration}

\section{Parameters that Apply}

The SD integration parameters that remain from steps 1 and 2 can be performed for this project. Chapter 4 of the Site Integration Roadmap gives guidance on how to address each of these integration activities.

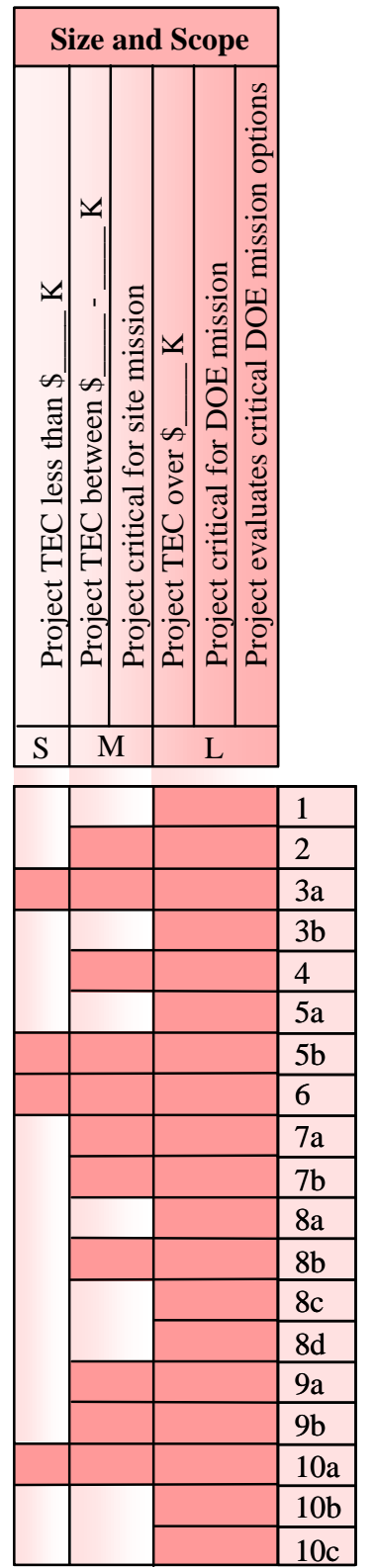

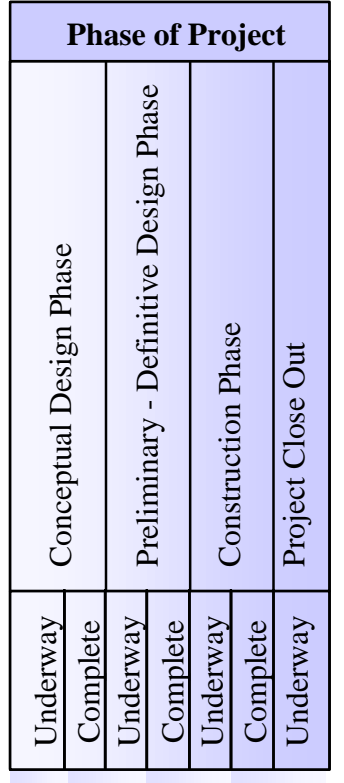

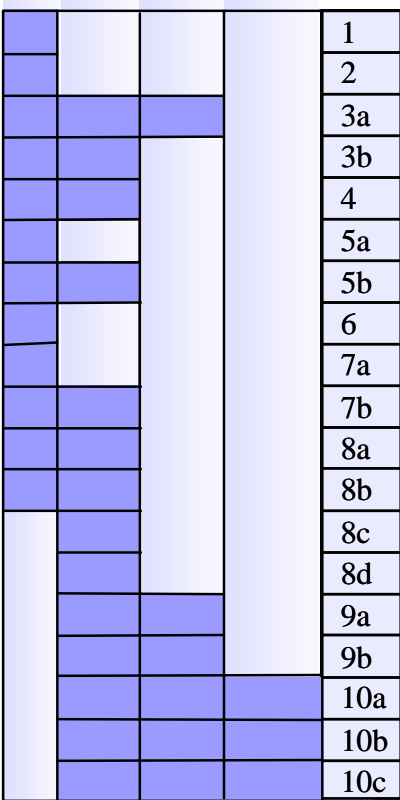

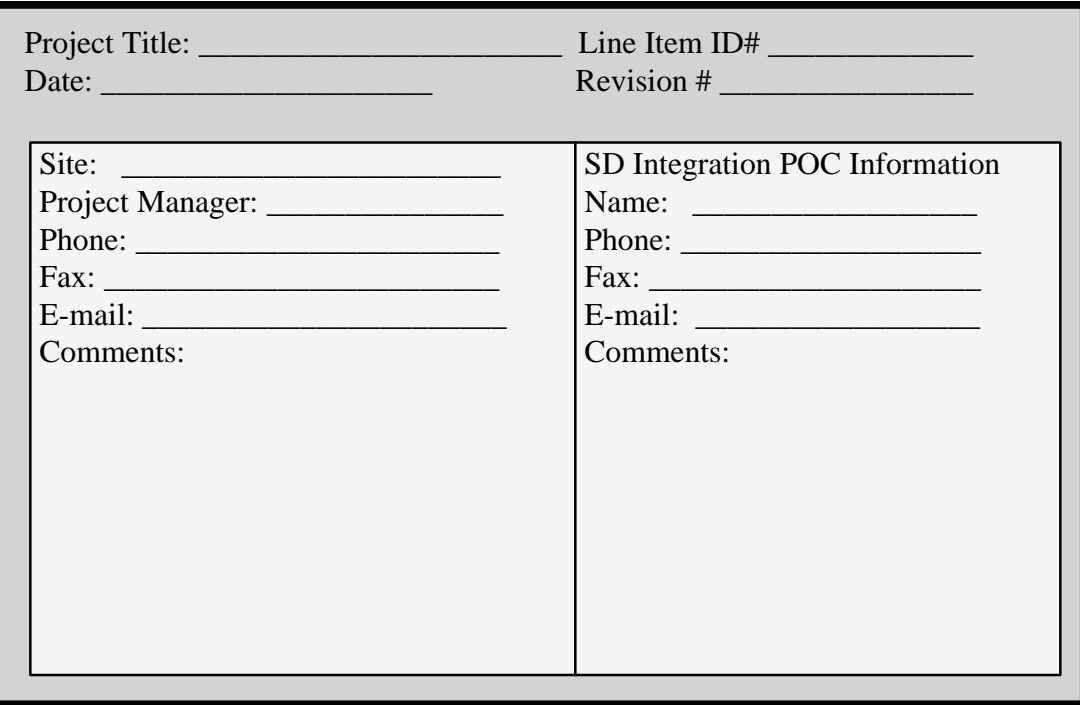

\begin{tabular}{|l|l|l|}
\hline$\#$ & Project-Level SD Integration Activity Parameters & Completed \\
\hline 1 & Integrate SD into project charter & \\
\hline 2 & SD included in budget planning & \\
\hline 3a & SD project lead assigned & \\
\hline $3 \mathrm{~b}$ & SD team established & \\
\hline 4 & Project team receives SD training & \\
\hline $5 \mathrm{a}$ & Integrate SD into VE Studies & \\
\hline $5 \mathrm{~b}$ & Integrate SD into NEPA documentation & \\
\hline 6 & Document SD integration in Conceptual Design documents & \\
\hline $7 \mathrm{a}$ & Incorporate SD into Project Cost Baselines & \\
\hline $7 \mathrm{~b}$ & Revise cost baselines to include SD opportunity LCC savings & \\
\hline $8 \mathrm{a}$ & Quantify waste and material streams & \\
\hline $8 \mathrm{~b}$ & I.D. SD opportunities & \\
\hline $8 \mathrm{c}$ & SD opportunity feasibility analysis and selection & \\
\hline $8 \mathrm{~d}$ & Track implementation of SD opportunities & \\
\hline 9a & Integrate SD into design/build subcontracts & \\
\hline 9b & Incorporate SD into construction planning and methods & \\
\hline 10a & Verify implementation of design opportunities & \\
\hline 10b & Create Operations SD plan or manual & \\
\hline 10c & Incorporate SD into D\&D plan & \\
\hline
\end{tabular}




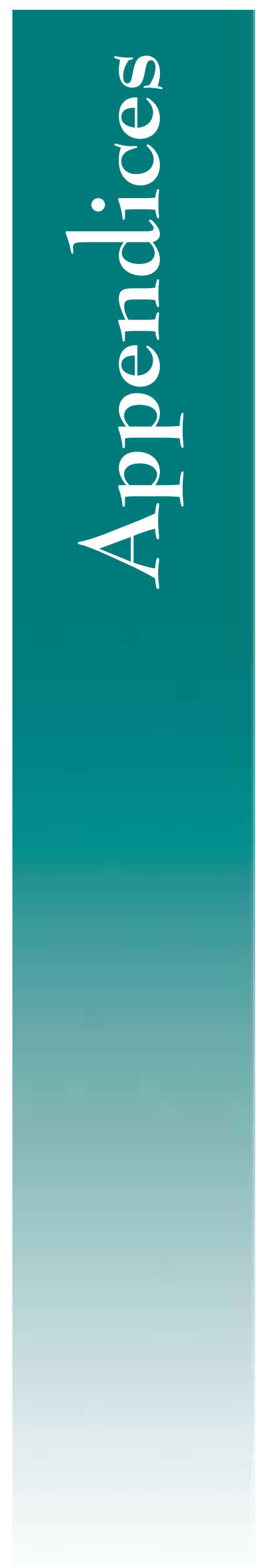




\section{Appendix A: References and Additional Resources}

\section{A.1 Design for Environment (DfE) - General}

Brezet, Han, and Carolien van Hemel. 1997. ECODESIGN: A Promising Approach to Sustainable Production and Consumption. Delft University of Technology, The Netherlands.

Chemical Manufacturers Association. 1993. Designing Pollution Prevention into the Process: Research, Development, and Engineering. Washington, D.C.

Ellis, M. D. (editor). 1994. The Role of Engineering in Sustainable Development. American Association of Engineering Societies, Washington, D.C.

Fiksel, J. 1996. Design for Environment: Creating Eco-Efficient Products and Processes. McGrawHill, New York.

Graedel, T.E., and B. R. Allenby. 1995. Industrial Ecology. Prentice Hall, Englewood Cliffs, New Jersey.

Guiding Principles of Sustainable Design. 1993. National Park Service. Government Printing Office. (The National Park Service's illustrated guidelines for sustainable design. Includes chapters on interpretation, natural and cultural resources, site and building design, energy management, water, waste prevention, and maintenance and operations.)

Kennedy, M. 1998. "Gathering Environmental Cost Data for P2.” P2/Pollution Prevention Review. Tampa, Florida.

Kilbert, C. and D.L. Waller. 1992. Guidelines for Contractors Dealing with Environmental Issues. Technical Publication No. 77, University of Florida.

Weitz, K., J. Smith, and J. Warren. 1994. "Developing a Decision Support Tool for Life Cycle Cost Assessments." Total Quality Environmental Management, Autumn 1994.

\section{A.2 Environmentally Preferred Materials}

Clean Washington Center. Directory of Recycled Content Building \& Construction Products. 1992. (A listing, by CSI code of building and construction products containing recycled materials). Contact: Send requests for this publication to Clean Washington Center, Department of Trade \& Economic Development, 2001 6th Ave, Suite 2700, Seattle, WA 98121, 206/464-7040.

Environmental Building News Product Catalog. "What's Working." P.O. Box 1004, Boulder, CO 80306 - e-mail: mailto:catalog@ whatsworking.com. 
Kalin Associates. Green Spec. Green Products Software. (See Software Products below.)

Loken, S., W. Spurling and C. Price. 1993. Guide to Resource Efficient Building Elements. Center for Resourceful Building Technology (CRBT) (Listing of a number of "resource efficient" construction products.)

Lopenske, B. NPS Sustainable Design and Construction Database. Available for download at http://www.nps.gov/dsc/dsgnenstr/.

National Park Service. Sustainable Construction and Design Database.

St. John, A., (editor). The Sourcebook for Sustainable Design. Architects for Social Responsibility, Boston Society of Architects. (Guide to environmentally responsible building materials and processes.)

Stafford Harris, Inc. 1995. The Harris Directory. Second Edition. (See Software Products below.) (Electronic listing of 1,800 environmentally preferable building and construction products, with sorting capability by state, CSI code, etc.)

Sullivan, B. Resources for Environmental Design Index (REDI). Iris Communications, Inc. Internet address: http://oikos.com/ E-mail: iris@oikos.com.

\section{A.3 Green Design Manuals and Case Studies}

American Institute of Architects. 1996. AIA Environmental Resource Guide, available through AIA order department, 800/365-ARCH.

Austin Green Builder Program. The Sustainable Building Sourcebook http://www.greenbuilder.com/sourcebook/.

U.S. Department of Energy Project and Fixed Asset Management (FM-20). 1996. Good Practice Guide for Pollution Prevention: FM-GPG-025.

U.S DOE Center of Excellence for Sustainable Development. 1996. The Green Building Technical Manual, available for download from http://www.sustainable.doe.gov.

Kincade, J. Waste Spec. Manual for specifying pollution prevention in construction contracts (see page A-10 for further contact information).

Mumma, T. 1997. Guide to Resource Efficient Building Elements, $6^{\text {th }}$ edition. The Center for Resourceful Building Technology, Missoula, Montana.

Pacific Northwest National Laboratory. 1996. P2-EDGE Software (Pollution Prevention Environmental Design Guide for Engineers). (See Software Products.) Contains a database of over 250 opportunities to incorporate pollution prevention into facility design.

Rocky Mountain Institute. 1997. Green Developments. (See Software Products.) A database of over 100 case-study projects that demonstrate environmentally-responsible building development on CD-ROM. 
U.S. Department of Energy. 1997. Greening Federal Facilities: An Energy, Environmental, and Economic Resource Guide for Federal Facility Managers. Greening America, Sustainable Systems, Inc., Washington, D.C.

U.S. Environmental Protection Agency. 1997. "Greening the Government." Closing the Circle News. Also available at http://www.ofee.gov/ (Office of Federal Environmental Executive), Washington, D.C.

U.S. Department of Defense. 1999. "Whole Building Design Guide, available at http://www.wbdg.org.

\section{A.4 Software Products}

\section{A.4.1 Databases}

Kalin Associates. Green Spec, Green Products Software. Cost \$125. Available through Kalin Associates, 154 Wells Ave., Newton Centre, MA 02159, 617/964-5477.

Lopenske, B. NPS Sustainable Design and Construction Database. Available for download at http://www.nps.gov/dsc/dsgnenstr/.

Pacific Northwest National Laboratory. 1996. P2-EDGE Software (Pollution Prevention Environmental Design Guide for Engineers). Available by calling Kim Fowler, Pacific Northwest National Laboratory, 509/372-4233, or mailto:kim.fowler@pnl.gov.

Rocky Mountain Institute. 1997. Green Developments. A database of over 100 case-study projects that demonstrate environmentally responsible building development on CD-ROM. The CD-ROM is available for $\$ 10$ through the Center for Renewable Energy and Sustainable Technology (CREST) at: CREST, 1200 $18^{\text {th }}$ St., NW, Suite 900, Washington, D.C. 20036.

Fax: 202-887-0497, Internet address: http://solstice.crest.org/.

Stafford Harris, Inc. 1995. The Harris Directory. Second Edition. (An Excel 4.0 spreadsheet/database listing of 1,800 environmentally preferable building and construction products. Extracting and sorting capability by state, CSI code, etc. Price is approximately $\$ 80$.)

Contact: B. J. Harris, Stafford Harris Inc., Architecture Resources, 1916 Pike Place, \#705, Seattle, WA 98101-1056, 206/682-4042, fax: 206/447-1640, mailto:stafford@igc.apc.org.

Sullivan, Bruce. Resources for Environmental Design Index (REDI), Iris Communications, Inc. Internet address: http://oikos.com/ E-mail: iris@oikos.com.

\section{A.4.2 Financial Software}

Fuller, L. Building Life cycle Cost (BLCC), Software. Can be downloaded directly from http://www.eren.doe.gov/femp (under technical assistance/analytical software tools).

U.S. EPA, P2/Finance Software. Available free of charge through the EPA's Pollution Prevention Information Clearinghouse, MC 3404, 401 M St. SW, Washington, D.C. 20460 202/260-1023. 


\section{A.5 Internet Resources and Citations}

1998 DOE Pollution Prevention Conference proceedings:

http://www.hanford.gov/polprev/conference/index.htm

DOE Center of Excellence for Sustainable Development:

http://www.sustainable.doe.gov

DOE Federal Energy Management Program:

http://www.eren.doe.gov/femp/

DOE P2 by Design Training:

http://p2.pnl.gov:2080/DFE/prod.htm

DOE Site $\mathrm{P} 2$ by Design Action Plans:

http://p2.pnl.gov:2080/DFE/doe-impl.htm

Good Practice Guide -- Pollution Prevention: FM-GPG-025A:

http://www.fm.doe.gov/FM-20/guides.htm

Green Fees: Getting Paid for Getting It Right, article:

http://www.rmi.org/gds/pbf/index.html

P2 by Design Technical Resource Center website:

http://engineering.ornl.gov/projects/p2d/

P2/Finance Software:

http://es.epa.gov/techinfo/finance/finance2.html

Rocky Mountain Institute:

http://www.rmi.org/ 


\section{A.6 Regulations, DOE Orders, and Procedures Governing Design}

10 CFR 435, Energy Conservation Voluntary Performance Standards for Commercial and Multi-Family High Rise Residential Buildings; Mandatory for New Federal Buildings; Interim Rule. Federal Register, January 30, 1989.

10 CFR Chapter. III (1-1-96 Edition), Subpart K - Design and Control, Section 835.1002

Facility Design and Modifications. [paragraph (d): "The design or modification of a facility and the selection of materials shall include features that facilitate operations, maintenance, decontamination, and decommissioning."]

U.S. DOE. March 1994. Federal Users Manual: Performance Standards for New Commercial and Multi-Family High Rise Residential Buildings. Assistant Secretary Energy Efficiency and Renewable Energy Office of Codes and Standards. (Guidance for compliance with 10 CFR 435.)

U.S. DOE. March 1994. Federal Users Manual: Performance Standards for New Commercial and Multi-Family High Rise Residential Buildings. Assistant Secretary Energy Efficiency and Renewable Energy Office of Codes and Standards. (Guidance for compliance with 10 CFR 435.)

U.S. Environmental Protection Agency, Closing the Circle News. 1997. Greening the Government. Also available at http://www.ofee.gov/ (Office of Federal Environmental Executive), Washington, D.C.

The following DOE Documents are controlled by the Office of Project and Fixed Asset Management (FM20) and can be viewed at http://www.fm.doe.gov/FM-20/products.htm

DOE Order 430.1 Life Cycle Asset Management

With Supporting Good Practice Guides:

-GPG-FM-001, Project Management Overview

-GPG-FM-002, Critical Decision Criteria

-GPG-FM-003, Engineering Tradeoff Studies

-GPG-FM-004, Reliability, Maintainability, Availability Planning

-GPG-FM-005, Test and Evaluation

-GPG-FM-006, Performance Analysis and Reporting

-GPG-FM-007, Risk Analysis and Management

-GPG-FM-008, Work Scope Planning

-GPG-FM-009, Baseline Change Control

-GPG-FM-010, Project Execution and Engineering Management Planning

-GPG-FM-011, Value Engineering

-GPG-FM-012, Configuration Data and Management

-GPG-FM-013, Interface Management

-GPG-FM-014, Program and Project Relationships

-GPG-FM-015, Project Reviews

-GPG-FM-016, Baseline Development

-GPG-FM-017, Quality Assurance

-GPG-FM-019, Project Budget Process

-GPG-FM-020, Performance Measures

-GPG-FM-021, Environmental Interfaces 
-GPG-FM-022, Public Participation

-GPG-FM-023, Safety Analysis

-GPG-FM-024, Site Development Planning

-GPG-FM-025A, Pollution Prevention

-GPG-FM-026A, Project Closeout

-GPG-FM-027, Human Factors Engineering

-GPG-FM-028, Productivity Tools; Models and Simulations

-GPG-FM-029, Disposal Analysis and Assessment

-GPG-FM-030, Prioritization

-GPG-FM-031, Maintenance

-GPG-FM-032A, Life Cycle Cost

-GPG-FM-033, Comprehensive Planning

Cost Estimating Guide, Volume 6

The following matrix (Figure A.1) can be used to help navigate Appendixes A.7 and A.8. The matrix shows the I.D numbers for specific example and resource citations that correspond to the Project-Level Integration Parameters discussed in Chapter 4.0 of the Roadmap.

\section{Figure A.1}

\begin{tabular}{|l|l|l|l|}
\hline$\#$ & Project-Level SD Integration & $\begin{array}{c}\text { Examples } \\
\text { Apx. A.7) }\end{array}$ & $\begin{array}{l}\text { Resources } \\
\text { Apx. A.8) }\end{array}$ \\
\hline 1 & Integrate SD into project & - & 1 \\
\hline 2 & SD included in budget & - & - \\
\hline 3 & SD project lead & 6, & 1 \\
\hline $3 \mathrm{~b}$ & SD team & $1-5$ & 1 \\
\hline 4 & Project team receives SD & $1-5$ & 1, \\
\hline 5 & Integrate SD into VE & 4 & 1 \\
\hline $5 \mathrm{~b}$ & Integrate SD into NEPA & - & 1, \\
\hline 6 & Document SD integration in Conceptual Design & 5 & - \\
\hline 7 & Incorporate SD into Project Cost & - & $7,8,15$, \\
\hline $7 \mathrm{~b}$ & Revise cost baselines to include SD opportunity LCC & - & $7,8,15$, \\
\hline 8 & Quantify waste and material & 5 & 1, \\
\hline $8 \mathrm{~b}$ & I.D. SD & $1-4$, & $1-$ \\
\hline $8 \mathrm{c}$ & SD opportunity feasibility analysis and & $1-4$, & $1,2,4,6-8,15-$ \\
\hline $8 \mathrm{~d}$ & Track implementation of SD & 4 & 1 \\
\hline 9 & Integrate SD into design/build & 8 & 9,10, \\
\hline $9 \mathrm{~b}$ & Incorporate SD into construction planning and & - & $10,11,13$, \\
\hline 10 & Verify implementation of design & - & 1 \\
\hline 10 & Create Operations SD plan or & - & - \\
\hline $10 \mathrm{c}$ & Incorporate SD into D\&D & - & - \\
\hline & & & \\
\hline
\end{tabular}

\section{A.7 Example DOE Projects That Have Implemented Sustainable Design}

Select projects from within DOE are listed in Table A.7 to illustrate some of the SD activities identified in Section 4.1. The numbers in the first column of the table correspond to the "Examples" column from Figure A.1. 
Table A.7 - Examples

\begin{tabular}{|c|c|c|c|c|}
\hline$\#$ & Project Title & Site & $\begin{array}{l}\text { Performed these } \\
\text { Project-level } \\
\text { Integration } \\
\text { Activities } \\
\end{array}$ & Successes \\
\hline 1 & $\begin{array}{l}\text { Classified Waste Landfill, } \\
\text { Environmental Restoration Site } \\
\# 2\end{array}$ & SNL(a) & $3 b, 4,8 b, 8 c$ & $\begin{array}{l}\text { - } 25 \text { opportunities identified and } 22 \\
\text { investigated further, including a } \\
\text { cost/benefit analysis. } \\
\text { - } \quad \text { Five opportunities submitted for } \\
\text { DOE return-on-investment funding } \\
\text { and were partially funded. } \\
\text { Nominated by DOE-AL for a Team } \\
\text { Quality Award. }\end{array}$ \\
\hline 2 & $\begin{array}{l}\text { Moonlight Shot Area, } \\
\text { Environmental Restoration Sites } \\
\text { \#68 \& } 71\end{array}$ & SNL & $3 \mathrm{~b}, 4,8 \mathrm{~b}, 8 \mathrm{c}$ & $\begin{array}{l}\text { Eighteen opportunities were } \\
\text { identified and } 15 \text { were fully } \\
\text { evaluated. }\end{array}$ \\
\hline 3 & $\begin{array}{l}\text { Building } 906 \text { Decontamination } \\
\text { \& Demolition }\end{array}$ & SNL & $3 b, 4,8 b, 8 c$ & $\begin{array}{l}\text { - Twenty opportunities were } \\
\text { analyzed for implementation. } \\
\text { Most of the recommended } \\
\text { opportunities can be immediately } \\
\text { incorporated into the design project } \\
\text { with no additional implementation } \\
\text { costs, resulting in waste reduction } \\
\text { and a reduction in waste } \\
\text { management costs. }\end{array}$ \\
\hline 4 & $\begin{array}{l}\text { Kansas City Plant II, Stockpile } \\
\text { Management Restructuring } \\
\text { Initiative }\end{array}$ & $\mathrm{KCP}(\mathrm{b})$ & $\begin{array}{l}3 \mathrm{~b}, 4,5 \mathrm{z}, 8 \mathrm{~b}, 8 \mathrm{c} \\
8 \mathrm{~d}\end{array}$ & $\begin{array}{l}\text { P2DA became an integral part of } \\
\text { the ongoing VE study } \\
\text { Saved approximately } \$ 1.6 \mathrm{M}- \\
\$ 1.1 \mathrm{M} \text { from reductions already in } \\
\text { the project plan and } \$ 500 \mathrm{~K} \text { in new } \\
\text { savings as a result of the P2DA. }\end{array}$ \\
\hline 5 & Tritium Extraction Facility & SRS(c) & $3 \mathrm{~b}, 4,6,8 \mathrm{a}$ & $\begin{array}{l}\text { Detailed assessment of anticipated } \\
\text { waste streams. }\end{array}$ \\
\hline 6 & $\begin{array}{l}\text { Initial Tank Waste Retrieval } \\
\text { System (W-211) }\end{array}$ & Hanford(d) & $3 a, 8 b, 8 c$ & $\begin{array}{l}\text { - } \quad \text { Cost/benefit analysis of P2 } \\
\text { Options. } \\
\text { - } \quad \text { Saved over } \$ 1 \mathrm{M} \text { by implementing } \\
4 \mathrm{P} 2 \text { initiatives during detailed } \\
\text { design. }\end{array}$ \\
\hline 7 & $\begin{array}{l}\text { Chemical and Metallurgy } \\
\text { Research Facility (CMR) }\end{array}$ & LANL(e) & $3 a$ & $\begin{array}{l}\text { - Saved an estimated } \$ 50,278,000 \\
\text { through reuse of soils and } \\
\text { ductwork; capital equipment } \\
\text { replacement and upgrade; and } \\
\text { recycling lead and copper. }\end{array}$ \\
\hline 8 & $\begin{array}{l}\text { Advanced Process Engineering } \\
\text { Laboratory (APEL) }\end{array}$ & Hanford & $9 \mathrm{a}$ & $\begin{array}{l}\text { P2 incorporated into bid review } \\
\text { criteria. } \\
\text { - Saved over } \$ 400 \mathrm{~K} \text { from using } \\
\text { excess casework. }\end{array}$ \\
\hline
\end{tabular}

a) SNL - Sandia National Laboratory, Albuquerque, New Mexico

b) KCP - Kansas City Plant, Kansas City, Missouri

c) SRS - Savannah River Site, Aiken, South Carolina

d) Hanford - Hanford Site, Richland, Washington

e) LANL - Los Alamos National Laboratory, Los Alamos, New Mexico 


\section{A.8 Annotated Matrix of Project-Level SD Resources:}

The following references (Table A.8) are especially useful and relevant for implementing pollution prevention into design at the project level. The reference numbers in the first column of the table correspond to those cited in Resources column of the matrix in Figure A.1 (above).

\section{Table A.8 Project-Level Integration Resources}

\begin{tabular}{|c|c|c|c|c|}
\hline$\#$ & Title/Citation & $\begin{array}{l}\text { Type of } \\
\text { Resource }\end{array}$ & $\begin{array}{l}\text { Supports these } \\
\text { project-level } \\
\text { integration } \\
\text { parameters }\end{array}$ & Synopsis \\
\hline 1 & $\begin{array}{l}\text { GPG-FM-025, Waste } \\
\text { Minimization/Pollution } \\
\text { Prevention } \\
\text { http://www.fm.doe.gov/FM- } \\
\text { 20/guides.htm }\end{array}$ & Document & $\begin{array}{l}1,3 \mathrm{a}, 3 \mathrm{~b}, 4,5 \mathrm{a}, \\
5 \mathrm{~b}, 8 \mathrm{a}, 8 \mathrm{~b}, 8 \mathrm{c} \\
8 \mathrm{~d}, 10 \mathrm{a}\end{array}$ & $\begin{array}{l}\text { DOE's good practice guide for } \\
\text { implementing pollution preven- } \\
\text { tion during design. Contains an } \\
\text { overview of green design basics, } \\
\text { then step-by-step instructions for } \\
\text { completing a Pollution } \\
\text { Prevention Design Assessment } \\
\text { (P2DA). }\end{array}$ \\
\hline 2 & $\begin{array}{l}\text { The Green Building Technical } \\
\text { Manual } \\
\text { DOE Center of Excellence for } \\
\text { Sustainable Development } \\
\text { 1617 Cole Blvd., } \\
\text { Golden, CO 80401, } \\
\text { available for download } \\
\text { from } \\
\text { http://www.sustainable.doe.gov }\end{array}$ & Document & $4,5 b, 8 a, 8 b, 8 c$ & $\begin{array}{l}\text { A manual for designing, } \\
\text { operating, and maintaining } \\
\text { environmentally friendly } \\
\text { buildings. Over } 300 \text { pages of } \\
\text { detailed suggestions written by } \\
\text { over } 24 \text { leading experts. } \\
\text { Designed to synthesize the large } \\
\text { volume of information available } \\
\text { on green buildings. Extremely } \\
\text { comprehensive. Would make a } \\
\text { good text for DfE training, or a } \\
\text { good reference manual to project } \\
\text { teams for overall P2 planning } \\
\text { and identifying opportunities. }\end{array}$ \\
\hline 3 & $\begin{array}{l}\text { The Sustainable Building } \\
\text { Sourcebook } \\
\text { http://www.greenbuilder.com } \\
\underline{\text { /sourcebook/ }}\end{array}$ & Document & $8 b$ & $\begin{array}{l}\text { Created by the Austin Green } \\
\text { Builder Program, this } 400 \text {-page } \\
\text { document is being converted to } \\
\text { html format for direct download. } \\
\text { Contains sections on water, } \\
\text { energy, building materials, and } \\
\text { waste. }\end{array}$ \\
\hline
\end{tabular}




\begin{tabular}{|c|c|c|c|c|}
\hline 4 & $\begin{array}{l}\text { Greening of Federal Facilities } \\
\text { Manual; DOE-EE- } 0123\end{array}$ & Document & $8 b, 8 c$ & $\begin{array}{l}\text { An energy, environmental, and } \\
\text { economic resource guide for } \\
\text { Federal facility managers. Over } \\
140 \text { pages covering the rationale } \\
\text { and regulatory drivers for green } \\
\text { design; decision methods and } \\
\text { economic analysis tools; and } \\
\text { detailed design considerations } \\
\text { for energy systems, water and } \\
\text { wastewater, materials, waste } \\
\text { management, recycling, land- } \\
\text { scaping, indoor environmental } \\
\text { quality, operations and mainte- } \\
\text { nance, and management. }\end{array}$ \\
\hline 5 & $\begin{array}{l}\text { Center for Resourceful Building } \\
\text { Technology (CBRT) Guide to } \\
\text { Resource Efficient Building } \\
\text { Elements } \\
\text { P.O. Box 100, Missoula, } \\
\text { MT 59806 }\end{array}$ & Document & $8 b$ & $\begin{array}{l}\text { Detailed guide for resource } \\
\text { efficient material selection and } \\
\text { construction methods. Covers } \\
\text { foundations and block walls, } \\
\text { framing, panel systems, sheath- } \\
\text { ing and wallboard, roofing, } \\
\text { siding and exterior trim, } \\
\text { insulation, windows and doors, } \\
\text { interior finishes, floor coverings, } \\
\text { salvaged materials, landscaping, } \\
\text { job site recycling, and } \\
\text { indigenous building. For each } \\
\text { topic covered an overview is } \\
\text { provided followed by a listing of } \\
\text { vendors and contact } \\
\text { information. }\end{array}$ \\
\hline 6 & $\begin{array}{l}\text { AIA Environmental Resource } \\
\text { Guide } \\
\text { AIA Order Department, } 9 \\
\text { Jay Gould Court, PO Box } \\
\text { 753, Waldorf, MD 20604, } \\
\text { Phone: 800/365-ARCH, fax: } \\
\text { 800/678-7102 }\end{array}$ & Document & $8 b, 8 c$ & $\begin{array}{l}\text { Updated in 1996, this 600-page } \\
\text { 3-ring binder contains } \\
\text { information for design } \\
\text { professionals to incorporate } \\
\text { environmental criteria into } \\
\text { design decisions. It is well } \\
\text { formatted with easy access to } \\
\text { both in-depth product detail and } \\
\text { at-a-glance reference charts. } \\
\text { Contains Project Reports of case } \\
\text { studies, Application Reports } \\
\text { comparing material performance } \\
\text { and environmental concerns } \\
\text { within product categories, and } \\
\text { Materials Reports detailing life } \\
\text { cycle impacts in } 20 \text { categories of } \\
\text { building materials. }\end{array}$ \\
\hline 7 & $\begin{array}{l}\text { "Developing a decision support } \\
\text { tool for LCC Cost Assessment," } \\
\text { Total Quality Environmental } \\
\text { Management, Autumn 1994, } \\
\text { John Wiley \& Sons }\end{array}$ & Document & $7 \mathrm{a}, 7 \mathrm{~b}, 8 \mathrm{c}$ & $\begin{array}{l}\text { A good primer of Environ- } \\
\text { mental Life Cycle framework } \\
\text { and tools. }\end{array}$ \\
\hline
\end{tabular}




\begin{tabular}{|c|c|c|c|c|}
\hline 8 & $\begin{array}{l}\text { "Gathering Environmental Cost } \\
\text { Data," P2Review, } 1998\end{array}$ & Document & $7 \mathrm{a}, 7 \mathrm{~b}, 8 \mathrm{c}$ & $\begin{array}{l}\text { Article defines useful cost data } \\
\text { elements to help perform Total } \\
\text { Cost Assessments }\end{array}$ \\
\hline 9 & $\begin{array}{l}\text { Green Fees: Getting Paid for } \\
\text { Getting it Right }\end{array}$ & Document & $9 a$ & $\begin{array}{l}\text { Article that discusses innovative } \\
\text { performance-based contract } \\
\text { incentives. }\end{array}$ \\
\hline 10 & $\begin{array}{l}\text { Green Developments } \\
\text { Available through CREST } \\
120018^{\text {th }} \text { St., NW, Suite } \\
\text { 900, Washinton, D.C. } \\
\text { 20036, Fax: } 202 / 887-0497 \\
\text { http://solstice.crest.org/ }\end{array}$ & CD-ROM & $8 b, 9 a, 9 b$ & $\begin{array}{l}\text { Describes real-estate projects in } \\
\text { which environmental con- } \\
\text { siderations are viewed as } \\
\text { opportunities to create funda- } \\
\text { mentally better buildings and } \\
\text { communities. Over } 100 \text { case- } \\
\text { study projects are demonstrated } \\
\text { on the CD-ROM. Available for } \\
\$ 10 \text {. }\end{array}$ \\
\hline 11 & $\begin{array}{l}\text { Waste Spec } \\
\text { Ms. Judy Kincade, } \\
\text { Triangle J Council of } \\
\text { Governments } \\
\text { P.O. Box 12276, Research } \\
\text { Triangle Park, NC 27709, } \\
\text { (919) 549-0551 }\end{array}$ & Document & $9 b$ & $\begin{array}{l}\text { This 114-page binder provides } \\
\text { architects and engineers with } \\
\text { background information and } \\
\text { model language for addressing } \\
\text { waste reduction, reuse, and } \\
\text { recycling before and during } \\
\text { construction and demolition. } \\
\text { Contains specifications tailored } \\
\text { to all } 16 \text { divisions of the CSI } \\
\text { format. Includes a sample waste } \\
\text { management plan for } \\
\text { construction contractors. Comes } \\
\text { with a disk containing model } \\
\text { specifications in a generic } \\
\text { format that can be cut and } \\
\text { pasted into a specifier's standard } \\
\text { specifications. }\end{array}$ \\
\hline 12 & $\begin{array}{l}\text { Green Spec } \\
\text { Kalin Associates, } 154 \text { Wells } \\
\text { Ave., Newton Centre, MA } \\
\text { 02159, (617) 964-5477 }\end{array}$ & Software & $8 \mathrm{a}$ & $\begin{array}{l}\text { A database of green products } \\
\text { and practices organized by CSI } \\
\text { Masterformat. Includes the pros } \\
\text { and cons of the existing product } \\
\text { or methodology and the green } \\
\text { alternative and supplies } \\
\text { specification language, which } \\
\text { users can incorporate into their } \\
\text { own projects. Cost: } \$ 125\end{array}$ \\
\hline 13 & $\begin{array}{l}\text { Resources for Environmental } \\
\text { Design Index (REDI) } \\
\text { Bruce Sullivan, Iris } \\
\text { Communications, Inc. } \\
\text { Tel: 541-484-9353, } \\
\text { Fax: } 541-484-1645 \\
\text { Web: http://oikos.com/, } \\
\text { E-mail: iris@ oikos.com }\end{array}$ & Database & $9 a, 9 b$ & $\begin{array}{l}\text { A free database of over } 1,800 \\
\text { companies providing green } \\
\text { products and services. Can } \\
\text { search by CSI division or by } \\
\text { company name. The Web } \\
\text { version, located at } \\
\text { http://oikos.com/index.html, is } \\
\text { updated weekly. Three times a } \\
\text { year, all companies in the } \\
\text { database are contacted for } \\
\text { current information. }\end{array}$ \\
\hline
\end{tabular}




\begin{tabular}{|c|c|c|c|c|}
\hline 14 & $\begin{array}{l}\text { NPS Sustainable Design and } \\
\text { Construction Database } \\
\text { Mr. Bob Lopenske, Denver } \\
\text { Service Center, 12795 W. } \\
\text { Alameda Parkway, P.O. Box } \\
\text { 25287, Denver, CO, 80225- } \\
\text { 0287 (303)969-5406. Also } \\
\text { available for download at } \\
\text { http://www.nps.gov/dsc/dsgncnstr/ }\end{array}$ & Database & 11 & $\begin{array}{l}\text { The sustainable design portion } \\
\text { of the database contains over } \\
1000 \text { products that can be } \\
\text { searched by manufacturing plant } \\
\text { location, CSI division, or } \\
\text { product type. Products are rated } \\
\text { in } 14 \text { environmental factors. } \\
\text { The construction portion of the } \\
\text { database contains information } \\
\text { and resources for construction } \\
\text { site recycling. The database is } \\
\text { available on } 4 \text { diskettes from the } \\
\text { National Park Service, or can be } \\
\text { downloaded directly. }\end{array}$ \\
\hline 15 & $\begin{array}{c}\text { Building Life-Cycle Cost (BLCC) } \\
\text { Ms. Linda Fuller, NIST - } \\
\text { Office of Applied Economics, } \\
\text { (301)975-6134. Can be } \\
\text { downloaded directly from } \\
\text { http://www.eren.doe.gov/femp } \\
\text { (under technical assistance/ } \\
\text { analytical software tools) }\end{array}$ & Software & 12 & $\begin{array}{l}\text { BLCC provides an economic } \\
\text { analysis of proposed capital } \\
\text { investments that are expected to } \\
\text { reduce long-term operating costs } \\
\text { of buildings or building systems. } \\
\text { Up to } 99 \text { alternative designs can } \\
\text { be evaluated simultaneously to } \\
\text { determine which has the lowest } \\
\text { life cycle cost. Several } \\
\text { economic measures, including } \\
\text { internal rate of return and } \\
\text { payback period can be computed } \\
\text { for each alternative. BLCC } \\
\text { complies with ASTM standards } \\
\text { related to building economics } \\
\text { and NIST Handbook 135, } \\
\text { Life Cycle Costing Manual for } \\
\text { the FEMP. }\end{array}$ \\
\hline 16 & $\begin{array}{l}\text { P2-EDGE (Pollution Prevention } \\
\text { Environmental Design Guide for } \\
\text { Engineers) } \\
\text { Kim Fowler } \\
\text { Pacific Northwest National } \\
\text { Laboratory } \\
\text { P.O. Box } 999 \\
\text { Richland, Washington } 99352 \\
\text { (509) 372-4233 }\end{array}$ & Software & 12 & $\begin{array}{l}\text { This software allows the query } \\
\text { of over } 250 \text { P2 design } \\
\text { opportunities (P2DOs). Facility } \\
\text { design engineers can identify } \\
\text { and select applicable P2DOs and } \\
\text { use the software to generate } \\
\text { reports documenting } \\
\text { implementation plans. }\end{array}$ \\
\hline 17 & $\begin{array}{l}\text { P2/Finance } \\
\text { Available through EPA's } \\
\text { Pollution Prevention Information } \\
\text { Clearinghouse, MC3404, } \\
\text { 401 M. St. SW } \\
\text { Washington, D.C. } 20460 \\
\text { 202/260-1023 }\end{array}$ & Software & $9,13,14$ & $\begin{array}{l}\text { A user-friendly spreadsheet } \\
\text { software program designed to } \\
\text { help with the data collection and } \\
\text { analysis for financial evaluation } \\
\text { of P2 projects. The software } \\
\text { uses Total Cost Assessment } \\
\text { (TCA) approach. }\end{array}$ \\
\hline
\end{tabular}




\section{A.9 Acronyms Used in Main Text}

$\begin{array}{ll}\text { A/E } & \text { Architecture and Engineering } \\ \text { APEL } & \text { Applied Process Engineering Laboratory } \\ \text { CDR } & \text { Conceptual Design Report } \\ \text { D\&D } & \text { Decontamination and Decommissioning } \\ \text { DfE } & \text { Design for Environment } \\ \text { EO } & \text { Executive Order } \\ \text { FEMP } & \text { Federal Energy Management Program } \\ \text { GSA } & \text { General Services Administration } \\ \text { LCC } & \text { Life Cycle Cost } \\ \text { NEPA } & \text { National Environmental Policy Act } \\ \text { P2/E2 } & \text { Pollution Prevention and Energy Efficiency } \\ \text { P2DA } & \text { Pollution Prevention Design Assessment } \\ \text { PPOA } & \text { Pollution Prevention Opportunity Assessment } \\ \text { SD } & \text { Sustainable Design } \\ \text { SDOs } & \text { Sustainable Design Opportunities } \\ \text { TEC } & \text { Total Estimated Cost } \\ \text { DOE } & \text { U.S. Department of Energy } \\ \text { DOE-FM } & \text { DOE-Field Management } \\ \text { EPA } & \text { U.S. Environmental Protection Agency } \\ \text { VE } & \text { Value Engineering }\end{array}$




\section{Appendix B: Supporting Documentation}

This section contains the following documents:

B.1 Memorandum of Understanding and Agreement Among the DOE, the EPA, and the GSA

B.2 February 26, 1999 Memorandum for Heads of Departmental Elements from Bill Richardson

B.3 The P2 by Design Draft Performance Measures: Energy Management and Pollution Prevention Performance Based Objectives, Measures, and Expectations

B.4 Executive Order 13101

B.5 Executive Order 13123 
B.1 Memorandum of Understanding and Agreement Among the DOE, the EPA, and the GSA

\author{
MEMORANDUM OF UNDERSTANDINO AND AQREEMENT \\ AMONO \\ THE OEPARTMENT OF ENERGY \\ THE ENYIRONMENTAL PROTECTION AGENCY AND \\ THE QENERAL BERVICES ADMINISTRATION
}

IN THE SPIRT OF COOPERATION, TO SUPPORT PRESIDENT CLINTON'S

CLIMATE CHANGE TECHNOLOOY INITIATIVE, TO HELP PROTECT THE ENVIRONMENT, TO WORK TOGETHER TOWARDS THE NATION'S ENVIRONMENTAL GOALS AND TO IMPROVE WORK CONDITIONS IN THE FEDERAL COMMUNITY AN UNDERSTANDINO AND AGREEMENT IS HEREBY ESTABLISHED AMONG THE DEPARTMENT OF ENERGY (DOE), THE ENVIRONMENTAL PROTECTION AGENCY (EPA) AND THE GENERAL SERVICES ADMINISTRATION (GSA) TO COOPERATE ON PLANET GSA. PLANET GSA INCLUDES FOUR PILLARS: BUY GREEN, BUILD GREEN, DRIVE GREEN ANO SAVE GREEN.

Buy Groon refers to using the purchasing power of the Federal Govemment to obtain products and sorvlces which have a reduced impact on the environment through waste minimlzaton, netural resouress conservatton and pollutton reduction and provention. Buying green ambodles a lite-cycle approech from materials exuraction to inal disposal or racyding and the employment of source reduction and poliution preventlon mothods, wherever feasible. Buylng greon linvolves purchesing products that have recycled content, are energy end/or water aficient, aro blo-based, and have other attributes that make these products environmentally preforable. Buylng green aloo encompasses the rouse or recycling of thase products. With support from DOE and EPA, GSA will encourage the purchase and $u s e$ of Energy star products and other appltoble products thet renk in the upper 25 percent in terms of energy efriciency. GSA will cortinue to promote all the onvtronmentsl products and semices in its supply system by highlighting them in thelr printed publications, 1dentifying them In thelr electronlc on-line shoppling service GSA Advantegel my and inrough notices to Purchase Card holders under the GSA Smart Pay Program.

Bulld Groen employs austainabla design ornciples to all phases of Federal raclittes - Inittal design, conatruction, remodeling. renovation and congtruction waste manegement. Such design princlples include ell olements of bullding and landscope deslan; maintsnence ano oporation activitse uaing water and toxlc substsncos such as pasteldes; and those actutites that impact indoor environmental qually and the recycing Inirastructure. Bulld Green promotes the bullding and renovating of Federal fecilitis using sustainable end low-energy design pilnclples. GSA, in collaboration with DOE and EPA, will promote the use of energy oficlancy and renswablo anergy technologlos. 
Drtve Grean promotes both elternatve commuting atrategles auch as teleWORKIng. carpooling, blke-to-work, and/or use of mass transht, along with effective and comprohenalve acquisition, management and operation of vahiclea in the Federal neet - whother owned or leased. As appropriate. neet programs incorporate moseurea aimed at achleving Alternative Fuelod Vehicle acquisition coals; maxmlzing fual economy performance; and maximizing the procurement of recycled, blo-based and other products with ottributes that make them environmentally preferable for all vehieles in the Federal feet.

Save Groen promotes the use of energy-eficient and water-conserving meanuras at Federal fecilltes and encourages the use of ranewable energy and anergy efillolent tochnologies. Savo Greon also promoses innovative tools such as the Energy Star label for bulldings and altemathe nnencing through Utility Agreomenta and Energy Savinga Parformance Contracts. G8A, whth "lfe-cycle" analytic support from DOE and EPA, will use those measures to complete all cost-fiective energy-saving projects, whare appropriate. As part of this effort, OSA, DOE and EPA wil sncourage the purchase of green power in a competitive slectricity anvironment. To support all of thess eiforts and ensuro implementation, where feasible, GSA will incorporate these principles Into policy. budget, design and operational dedelons. With support from DOE and EPA, within the terms of the delegation agreaments, GSA will work with its customer agencles to accelerate energy efficlency and renewable energy within delegated butidings.

THE PARTIES RECOGNIZE that a partnership concerning Pienet GSA will strongthen the working alliancs among the throe sgencios, help clitzens oppredate how government agencies are colleborating to support the environment, and further acknowledge the already good working ralatlonahlp among these agencies. The parties further recogntze that Increased emphasls on Buyling, Bullding. Driving and Saving Green can Improve mployeo productivity, help reduce emissions of graenhouse geses and alr pollutants, save taxpayers money, and improve our nstion's oconomic compettiveness. Through the tintaragency egreement, DOE, EPA and GSA will promote Planet GSA, distribute Planet GSA and energy hformation, and ralse awareness and educete the general population about Planet GSA as well as broader energy management and environmantal issues. 
SIGNATURES:

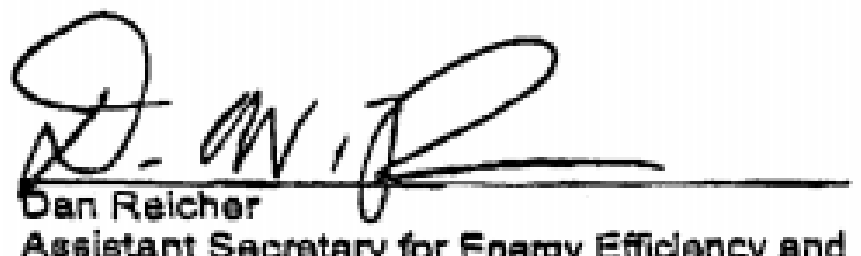

Assistant Secretary for Energy Efficiency and Renewable Energy

Department of Energy

$\frac{12 / 8 / 90}{\text { Date }}$

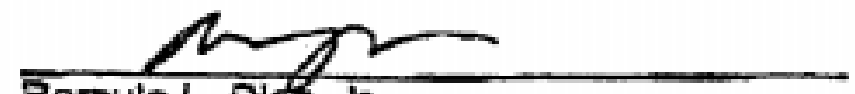

Rornuto L. DiR, Jr.

Assistant Administrator

Office of Administration and Resources Management

Environmental! Protection Agency

$12 / 8 / 28$

Date

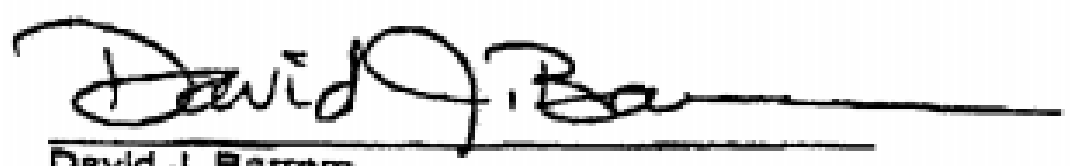

David J. Bertram

Administrator

General Services Administration

$\frac{12|<| 98}{0 \text { ate }}$

B-4 


\title{
B.2 February 26, 1999 Memorandum for Heads of Departmental Elements from Bill Richardson
}

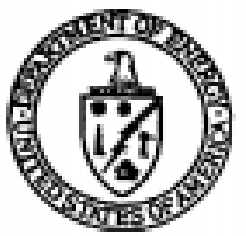

\author{
The Secretary of Energy \\ Washington, DC 20585 \\ February 26, 1999
}

\begin{abstract}
MEMORANDUM FOR HEADS OF DEPARTMENTAL ELEMENTS
FROM:

BILL RICHARDSON

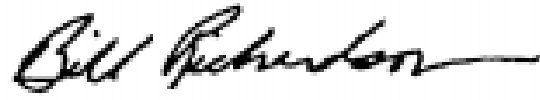

SUBJECT: $\quad$ Poliution Prevention and Energy Efficiency (P2/E2) at Department of Energy Facilities
\end{abstract}

On July 25, 1998, President Clinton directed a renewed effort by all Federal agencies to reduce energy consumption and to establish a strategy for continuing cost-saving energy management initiatives. Additionally, Executive Order 13101 , signed by President Clinton on September 14, 1998, requires all Federal agencies to increase their efforts in waste prevention, recycling, and the purchase of environmentally preferable products.

I am committed to making the Department of Energy a leader in pollution-free, energy-efficient operations in the Federal Government. To become that leader, we must continually improve our facilities to maximize energy efficiency and must strive toward "zero" waste and emissions.

I am directing that each Department Head undertake activities to prevent pollution and save energy and water. The Department can lower the future operating costs of our facilities by incorporating pollution prevention and energy efficiency $(\mathrm{P} 2 / \mathrm{E} 2)$ into the design and modification of all buildings and during all operations. Also, more efficient, less polluting operations and facilities will enhance worker safety and public bealth while protecting the environment.

I am asking the Deputy Secretary, supported by the Department's Environmental Executive, Dan Reicher, Assistant Secretary for Energy Efficiency and Renewable Energy, to regularly convene a Pollution Prevention and Energy Efficiency Executive Board that will set new goals for waste prevention, recycling, and energy and water conservation. During the next year, the Board will oversee implementation of additional projects that will ensure our continued success in pollution prevention and energy and water conservation. Please give the Deputy Secretary and the Environmental Executive your full support to enstre the Board's success. 


\title{
B.3 The P2 by Design Draft Performance Measures: Energy Management and Pollution Prevention Performance Based Objectives, Measures, and Expectations
}

\author{
Ref. FY1999-FY2000 Energy Efficiency Performance Agreements
}

Introduction

Current Energy Efficiency/Pollution Prevention (E2/P2) Performance Agreements contain an expectation that Operations Offices will incorporate sustainable design guidelines into the design and construction guidelines for new buildings. Implementation of the expectation is subject to issuance of DOE sustainable design guidelines. The expectation will be nullified if the guidelines are not available by the third quarter.

This addendum to E2/P2 performance agreements provides the DOE sustainable design guidelines cited. In addition, performance gradients and self-assessment information is included.

$\underline{\text { Background }}$

To facilitate achievement of E2/P2 performance agreement expectations and to implement Secretarial direction for sustainable design (ref. Letter, Bill Richardson to Heads of Departmental Elements, "Pollution Prevention and Energy Efficiency (P2/E2) at Department of Energy Facilities," dated February 26, 1999), a Sustainable Design Integration Protocol (appropriate reference) has been developed for the DOE. The Protocol identifies critical parameters that collectively ensure the systematic integration of P2/E2 into management systems, facility design processes and ultimately into the design of specific projects. The intent of the Protocol is to not provide prescriptive guidance but rather to ensure an effective, consistent approach across the DOE.

The EE Performance Agreement expectations for Sustainable Design implementation are based on several key Protocol parameters. As such, the performance expectations are broken down into three areas, with a program management element, infrastructure elements necessary to institutionalize sustainable design at a DOE facility, and an implementation element that addresses project-level integration of sustainable design. Following are the performance indicators for the EE Performance Agreement sustainable design expectation:

Program Management Indicator

1. Document a Sustainable Design(SD) Integration Baseline Review and Management Plan

Infrastructure Indicators

2. Integrate SD into Site Environmental Policy

3. Revise Site Design Program Procedures to specify SD considerations

4. Provide Site Level SD Training

Sustainable Design Implementation Indicators

5. Integrate SD into Site Design Projects

FY1999 performance will be based on progress towards completing program management and infrastructure indicators and FY2000 performance will be based on completion of infrastructure indicators with a performance measure for project-level implementation. 


\section{Draft}

\section{FY1999 PERFORMANCE INDICATORS}

Mechanisms are in place to build necessary program management and infrastructure to address Sustainable Design, using the DOE Sustainable Design Integration Protocol as a guide.

\section{Gradient:}

Far exceeds expectations - indicators 1 and 2 addressed; progress towards 3 and 4 Exceeds expectations - indicators 1 and 2 addressed

Meets expectations - indicator 1 addressed

Needs Improvement -0 indicators addressed

\section{FY2000 PERFORMANCE INDICATORS}

The necessary program management and infrastructure is in place to address Sustainable Design and SD concepts are being applied to relevant project designs, using the DOE Sustainable Design Integration Protocol as a guide.

\section{Gradient:}

Far exceeds expectations - indicators 1 though 4 addressed ; project-level SD checklist completed for $>75 \%$ relevant projects

Exceeds expectations - indicators 1 though 4 addressed ; project-level SD checklist completed for $>50 \%$ relevant projects

Meets expectations - indicators 1 though 4 addressed ; project-level SD checklist completed for $>25 \%$ relevant projects

Needs Improvement - indicators not complete 


\section{B.4 Executive Order 13101}

THE WHITE HOUSE

Office of the Press Secretary

(New York, New York)

For Immediate Release

September 14, 1998

EXECUTIVE ORDER 13101

\section{GREENING THE GOVERNMENT THROUGH WASTE PREVENTION, RECYCLING, AND FEDERAL ACQUISITION}

By the authority vested in me as President by the Constitution and the laws of the United States of America, including the Solid Waste Disposal Act, Public Law 89-272, 79 Stat. 997, as amended by the Resource Conservation and Recovery Act (RCRA), Public Law 94-580, 90 Stat. 2795, as amended (42 U.S.C. 6901-6907), section 301 of title 3, United States Code, and in order to improve the Federal Govemment's use of recycled products and environmentally preferable products and services, it is hereby ordered as follows:

\section{PART 1 - PREAMBLE}

Section 101. Consistent with the demands of efficiency and cost effectiveness, the head of each executive agency shall incorporate waste prevention and recycling in the agency's daily operations and work to increase and expand markets for recovered materials through greater Federal Government preference and demand for such products. It is the national policy to prefer pollution prevention, whenever feasible.

Pollution that cannot be prevented should be recycled; pollution that 
cannot be prevented or recycled should be treated in an environmentally safe manner. Disposal should be employed only as a last resort.

Sec. 102. Consistent with policies established by the Office of Federal Procurement Policy (OFPP) Policy Letter 92-4, agencies shall comply with executive branch policies for the acquisition and use of environmentally preferable products and services and implement cost-effective procurement preference programs favoring the purchase of these products and services.

Sec. 103. This order creates a Steering Committee, a Federal Environmental Executive (FEE), and a Task Force, and establishes Agency Environmental Executive (AEE) positions within each agency, to be responsible for ensuring the implementation of this order. The FEE, AEEs, and members of the Steering Committee and Task Force shall be full-time Federal Government employees.

\section{PART 2 - DEFINITIONS}

For purposes of this order:

Sec. 201. "Environmentally preferable" means products or services that have a lesser or reduced effect on human health and the environment when compared with competing products or services that serve the same purpose. This comparison may consider raw materials acquisition, production, manufacturing, packaging, distribution, reuse, operation, maintenance, or disposal of the product or senvice.

Sec. 202. "Executive agency" or "agency" means an executive agency as defined in 5 U.S.C. 105. For the purpose of this order, military departments, as defined in 5 U.S.C. 102, are covered under the auspices of the Department of Defense.

Sec. 203. "Postconsumer material" means a material or finished product that has served its intended use and has been discarded for disposal or recovery, having completed its life as a consumer item. 
"Postconsumer material" is a part of the broader category of "recovered material."

Sec. 204. "Acquisition" means the acquiring by contract with appropriated funds for supplies or services (including construction) by and for the use of the Federal Govemment through purchase or lease, whether the supplies or senvices are already in existence or must be created, developed, demonstrated, and evaluated. Acquisition begins at the point when agency needs are established and includes the description of requirements to satisfy agency needs, solicitation and selection of sources, award of contracts, contract financing, contract performance, contract administration, and those technical and management functions directly related to the process of fulfilling agency needs by contract

Sec. 205. "Recovered materials" means waste materials and by-products that have been recovered or diverted from solid waste, but such term does not include those materials and by-products generated from, and commonly reused within, an original manufacturing process (42 U.S.C. 6903 (19)).

Sec. 206. "Recyclability" means the ability of a product or material to be recovered from, or otherwise diverted from, the solid waste stream for the purpose of recycling.

Sec. 207. "Recycling" means the series of activities, including collection, separation, and processing, by which products or other materials are recovered from the solid waste stream for use in the form of raw materials in the manufacture of new products other than fuel for producing heat or power by combustion.

Sec. 208. "Waste prevention" means any change in the design, manufacturing, purchase, or use of materials or products (including packaging) to reduce their amount or toxicity before they are discarded. Waste prevention also refers to the reuse of products or materials. 
Sec. 209. "Waste reduction" means preventing or decreasing the amount of waste being generated through waste prevention, recycling, or purchasing recycled and environmentally preferable products.

Sec. 210. "Life cycle cost" means the amortized annual cost of a product, including capital costs, installation costs, operating costs, maintenance costs, and disposal costs discounted over the lifetime of the product.

Sec. 211. "Life cycle assessment" means the comprehensive examination of a product's environmental and economic aspects and potential impacts throughout its lifetime, including raw material extraction, transportation, manufacturing, use, and disposal.

Sec. 212. "Pollution prevention" means "source reduction" as defined in the Pollution Prevention Act of 1990 (42 U.S.C. 13102), and other practices that reduce or eliminate the creation of pollutants through: (a) increased efficiency in the use of raw materials, energy, water, or other resources; or (b) protection of natural resources by conservation.

Sec. 213. "Biobased product" means a commercial or industrial product (other than food or feed) that utilizes biological products or renewable domestic agricultural (plant, animal, and marine) or forestry materials.

Sec. 214. "Major procuring agencies" shall include any executive agency that procures over $\$ 50$ million per year of goods and services.

PART 3 - THE ROLES AND DUTIES OF THE STEERING COMMITTEE, FEDERAL ENVIRONMENTAL EXECUTIVE, TASK FORCE, AND AGENCY ENVIRONMENTAL EXECUTIVES

Sec. 301. Committees, Executives, and Task Force. (a) Steering Committee. There is hereby established a Steering Committee on Greening the Government through Waste Prevention and Recycling ("Steering Committee"). The Steering Committee shall be composed of the Chair of 
the Council on Environmental Quality (CEQ), the Federal Environmental Executive (FEE), and the Administrator for Federal Procurement Policy (OFPP). The Steering Committee, which shall be chaired by the Chair of the CEQ, is directed to charter a Task Force to facilitate implementation of this order, and shall provide the Task Force with policy direction in such implementation.

(b) Federal Environmental Executive. A Federal Environmental Executive, Environmental Protection Agency, shall be designated by the President. The FEE shall chair the Task Force described in subsection (c), take all actions necessary to ensure that the agencies comply with the requirements of this order, and generate a biennial report to the President.

(c) Task Force. The Steering Committee shall charter a Task Force on Greening the Government through Waste Prevention and Recycling ("Task Force"), which shall be chaired by the FEE and composed of staff from the major procuring agencies. The Steering Committee, in consultation with the agencies, shall determine the necessary staffing and resources for the Task Force. The major procuring agencies shall provide, to the extent practicable and permitted by law, resources and support to the Task Force and the FEE, upon request from the Steering Committee. The Task Force shall have the duty of assisting the FEE and the agencies in implementing this order, subject to policy direction provided by the Steering Committee. The Task Force shall report through the FEE to the Chair of the Steering Committee.

(d) Agency Environmental Executives (AEEs). Within 90 days after the date of this order, the head of each major procuring agency shall designate an AEE from among his or her staff, who serves at a level no lower than the Assistant Secretary level or equivalent, and shall notify the Chair of CEQ and the FEE of such designation.

Sec. 302. Duties. (a) The Federal Environmental Executive. The FEE, working through the Task Force, and in consultation with the AEEs, shall: 
(1) Develop a Govemment-wide Waste Prevention and Recycling Strategic Plan ("Strategic Plan") to further implement this order. The Strategic Plan should be initially developed within 180 days of the date of this order and revised as necessary thereafter. The Strategic Plan should include, but is not limited to, the following elements:

(a) direction and initiatives for acquisition of recycled and recyclable products and environmentally preferable products and senvices;

(b) development of affirmative procurement programs;

(c) review and revision of standards and product specifications;

(d) assessment and evaluation of compliance;

(e) reporting requirements;

(f) outreach programs to promote adoption of practices endorsed in this order; and

(g) development and implementation of new technologies that are of environmental significance.

(2) Prepare a biennial report to the President on the actions taken by the agencies to comply with this order. The report also may incorporate information from existing agency reports regarding Government-wide progress in implementing the following Executive Orders: 12843, Procurement Requirements and Policies for Federal Agencies for Ozone Depleting Substances; 13031, Federal Altemative Fueled Vehicle Leadership; 12845, Requiring Agencies to Purchase Energy Efficient Computer Equipment; 12856, Federal Compliance with Right-to-Know Laws and Pollution Prevention Requirements; 12902, Energy Efficiency and Water Conservation at Federal Facilities; and 12969, Federal Acquisition and Community Right-to-Know. 
(3) In coordination with the Office of Federal Procurement Policy, the Environmental Protection Agency (EPA), the General Services Administration (GSA), and the Department of Agriculture (USDA), convene a group of acquisition/procurement managers and environmental State, and local government managers to work with State and local govemments to improve the Federal, State, and local govemments' use of recycled products and environmentally preferable products and services.

(4) Coordinate appropriate Government-wide education and training programs for agencies.

(5) Establish committees and work groups, as needed, to identify, assess, and recommend actions to be taken to fulfill the goals, responsibilities, and initiatives of the FEE. As these committees and work groups are created, agencies are requested to designate appropriate personnel in the areas of procurement and acquisition, standards and specifications, electronic commerce, facilities management, pollution prevention, waste prevention, recycling, and others as needed to staff and work on these initiatives. An initial group shall be established to develop recommendations for tracking and reporting requirements, taking into account the costs and benefits of such tracking and reporting. The Steering Committee shall consult with the AEEs before approving these recommendations.

(b) Agency Environmental Executives. The AEEs shall:

(1) translate the Government-wide Strategic Plan into specific agency and service plans;

(2) implement the specific agency and service plans;

(3) report to the FEE on the progress of plan implementation;

(4) work with the FEE and the Task Force in furthering implementation of this order; and 
(5) track agencies' purchases of EPA-designated guideline items and report agencies' purchases of such guideline items to the FEE per the recommendations developed in subsection 302(a)(5) of this order. Agency acquisition and procurement personnel shall justify in writing to the file and to the AEE the rationale for not purchasing such items, above the micropurchase threshold (as set out in the Office of Federal Procurement Policy Act at 41 U.S.C. 428), and submit a plan and timetable for increasing agency purchases of the designated item(s).

(6) one year after a product is placed on the USDA Biobased Products List, estimate agencies' purchases of products on the list and report agencies' estimated purchases of such products to the Secretary of Agriculture.

PART 4 - ACQUISITION PLANNING, AFFIRMATIVE PROCUREMENT PROGRAMS, AND FEDERAL FACILITY COMPLIANCE

Sec. 401. Acquisition Planning. In developing plans, drawings, work statements, specifications, or other product descriptions, agencies shall consider, as appropriate, a broad range of factors including: elimination of virgin material requirements; use of biobased products; use of recovered materials; reuse of product; life cycle cost; recyclability; use of environmentally preferable products; waste prevention (including toxicity reduction or elimination); and ultimate disposal. These factors should be considered in acquisition planning for all procurement and in the evaluation and award of contracts, as appropriate. Program and acquisition managers should take an active role in these activities.

Sec. 402. Affimative Procurement Programs. (a) The head of each executive agency shall develop and implement affimative procurement programs in accordance with section 6002 of RCRA (42 U.S.C. 6962) and this order and consider use of the procurement tools and methods described in 7 U.S.C. 5909. Agencies shall ensure that responsibilities for preparation, implementation, and monitoring of affirmative procurement programs are shared between the program personnel and acquisition and procurement personnel. For the purposes 
of all purchases made pursuant to this order, EPA, in consultation with such other executive agencies as appropriate, shall endeavor to maximize environmental benefits, consistent with price, performance, and availability considerations, and constraints imposed by law, and shall adjust solicitation guidelines as necessary in order to accomplish this goal.

(b) Agencies shall establish affirmative procurement programs for all EPA-designated guideline items purchased by their agency. For newly designated items, agencies shall revise their internal programs within 1 year from the date the EPA designated the new items.

(c) Exclusive of the biobased products described in section 504, for the EPA-designated guideline items, which are contained in 40 CFR part 247, and for all future designated guideline items, agencies shall ensure that their affimative procurement programs require 100 percent of their purchases of products to meet or exceed the EPA guideline unless written justification is provided that a product is not available competitively within a reasonable time frame, does not meet appropriate performance standards, or is only available at an unreasonable price. Written justification is not required for purchases below the micropurchase threshold. For micropurchases, agencies shall provide guidance regarding purchase of EPA-designated guideline items. This guidance should encourage consideration of aggregating purchases when this method would promote economy and efficiency.

(d) Within 90 days after the date of this order, the head of each executive agency that has not implemented an affimative procurement program shall ensure that the affirmative procurement program has been established and is being implemented to the maximum extent practicable.

Sec. 403. Federal Facility Compliance. (a) Within 6 months of the date of this order, the Administrator of the EPA shall, in consultation with the Federal Environmental Executive, prepare guidance for use in determining Federal facility compliance with section 6002 of RCRA and the related requirements of this order. 
(b) EPA inspections of Federal facilities conducted pursuant to RCRA and the Federal Facility Compliance Act and EPA "multi-media" inspections carried out at Federal facilities will include, where appropriate, evaluation of facility compliance with section 6002 of RCRA and any implementing guidance.

(c) Where inspections of Federal facilities are carried out by authorized States pursuant to RCRA and the Federal Facility Compliance Act, the Administrator of the EPA will encourage those States to include evaluation of facility compliance with section 6002 of RCRA in light of EPA guidance prepared pursuant to subsection (a), where appropriate, similar to inspections performed by the EPA. The EPA may provide information and technical assistance to the States to enable them to include such considerations in their inspection.

(d) The EPA shall report annually to the Federal Environmental Executive on the results of inspections performed by the EPA to determine Federal facility compliance with section 6002 of RCRA not later than February 1st for those inspections conducted during the previous fiscal year.

\section{PART 5 - STANDARDS, SPECIFICATIONS, AND DESIGNATION OF ITEMS}

Sec. 501. Specifications, Product Descriptions, and Standards. When developing, reviewing, or revising Federal and military specifications, product descriptions (including commercial item descriptions), and standards, executive agencies shall consider recovered materials and any environmentally preferable purchasing criteria developed by the EPA, and ensure the criteria are complied with in developing or revising standards. Agencies shall report annually to the FEE on their compliance with this section for incorporation into the biennial report to the President referred to in section 302(a)(2) of this order. (a) If an inconsistency with section 6002 of RCRA or this order is identified in a specification, standard, or product description, the FEE shall request that the Environmental Executive of 
the pertinent agency advise the FEE as to why the specification cannot be revised or submit a plan for revising it within 60 days.

(b) If an agency is able to revise an inconsistent specification but cannot do so within 60 days, it is the responsibility of that AEE to monitor and implement the plan for revising it.

Sec. 502. Designation of Items that Contain Recovered Materials. In order to expedite the process of designating items that are or can be made with recovered materials, the EPA shall use the following process for designating these items in accordance with section 6002(e) of RCRA. (a) The EPA shall designate items that are or can be made with recovered material, by promulgating amendments to the Comprehensive Procurement Guideline (CPG). The CPG shall be updated every 2 years or as appropriate after an opportunity for public comment.

(b) Concurrent with the issuance of the CPG, the EPA shall publish for comment in the Federal Register Recovered Materials Advisory Notices that present the range of recovered materials content levels within which the designated items are currently available. These levels shall be updated periodically, after opportunity for public comment, to reflect changes in market conditions.

(c) Once items containing recovered materials have been designated by the EPA in the CPG, agencies shall modify their affimative procurement programs to require that, to the maximum extent practicable, their purchases of products meet or exceed the EPA guidelines unless written justification is provided that a product is not available competitively, not available within a reasonable time frame, does not meet appropriate performance standards, or is only available at an unreasonable price.

Sec. 503. Guidance on Acquisition of Environmentally Preferable Products and Services. (a) The EPA shall develop guidance within 90 days from the date of this order to address environmentally preferable purchasing. The guidance may be based on the EPA's September 1995 Proposed Guidance on the Acquisition of Environmentally Preferable 
Products and Services and comments received thereon. The guidance should be designed for Govemment-wide use and targeted towards products and services that have the most effect The guidance may also address the issues of use of the technical expertise of non-governmental entities and tools such as life cycle assessment in decisions on environmentally preferable purchasing. The EPA shall update this guidance every 2 years, or as appropriate.

(b) Agencies are encouraged to immediately test and evaluate the principles and concepts contained in the EPA's Guidance on the Acquisition of Environmentally Preferable Products and Services through pilot projects to provide practical information to the EPA for further updating of the guidance. Specifically:

(1) These pilot projects shall be focused around those product and service categories, including printing, that have wide use within the Federal Govemment. Priorities regarding which product and service categories to pilot shall be developed by the individual agencies and the EPA, in consultation with the OFPP, the FEE, and the appropriate agency procurement executives. Any policy disagreements shall be resolved by the Steering Committee.

(2) Agencies are encouraged to use all of the options available to them to determine the environmentally preferable attributes of products and services in their pilot and demonstration projects, including the use of technical expertise of nongovernmental entities such as labeling, certification, or standards-developing organizations, as well as using the expertise of the National Institute of Standards and Technology.

(3) Upon request and to the extent practicable, the EPA shall assist executive agencies in designing, implementing, and documenting the results of these pilot and demonstration projects.

(4) The EPA, in coordination with other executive agencies, shall develop a database of information about these projects, including, but not limited to, the number and status of pilot projects, examples of agencies' policy directives, revisions to specifications, solicitation 
procedures, and grant/contract policies that facilitate adoption of environmentally preferable purchasing practices, to be integrated on a commonly available electronic medium (e.g., Internet Web site). These data are to be reported to the FEE.

(c) Executive agencies shall use the principles and concepts in the EPA Guidance on Acquisition of Environmentally Preferable Products and Services, in addition to the lessons from the pilot and demonstration projects, to the maximum extent practicable, in identifying and purchasing environmentally preferable products and services and shall modify their procurement programs as appropriate.

Sec. 504. Designation of Biobased Items by the USDA. The USDA Biobased Products Coordination Council shall, in consultation with the FEE, issue a Biobased Products List (a) The Biobased Products List shall be published in the Federal Register by the USDA within 180 days after the date of this order and shall be updated biannually after publication to include additional items.

(b) Once the Biobased Products List has been published, agencies are encouraged to modify their affirmative procurement program to give consideration to those products.

Sec. 505. Minimum Content Standard for Printing and Writing Paper. Executive agency heads shall ensure that their agencies meet or exceed the following minimum materials content standards when purchasing or causing the purchase of printing and writing paper: (a) For high speed copier paper, offset paper, forms bond, computer printout paper, carbonless paper, file folders, white wove envelopes, writing and office paper, book paper, cotton fiber paper, and cover stock, the minimum content standard shall be no less than 30 percent postconsumer materials beginning December 31, 1998. If paper containing 30 percent postconsumer material is not reasonably available, does not meet reasonable performance requirements, or is only available at an unreasonable price, then the agency shall purchase paper containing no less than 20 percent postconsumer material. The Steering Committee, in consultation with the AEEs, may revise these levels if necessary. 
(b) As an altemative to meeting the standards in sections 505(a), for all printing and writing papers, the minimum content standard shall be no less than 50 percent recovered materials that are a waste material byproduct of a finished product other than a paper or textile product that would otherwise be disposed of in a landfill, as determined by the State in which the facility is located.

(c) Effective J anuary 1, 1999, no executive branch agency shall purchase, sell, or arrange for the purchase of, printing and writing paper that fails to meet the minimum requirements of this section.

Sec. 506. Revision of Brightness Specifications and Standards. The GSA and other executive agencies are directed to identify, evaluate, and revise or eliminate any standards or specifications unrelated to performance that present barriers to the purchase of paper or paper products made by production processes that minimize emissions of harmful byproducts. This evaluation shall include a review of unnecessary brightness and stock clause provisions, such as lignin content and chemical pulp requirements. The GSA shall complete the review and revision of such specifications within 6 months after the date of this order, and shall consult closely with the J oint Committee on Printing during such process. The GSA shall also compile any information or market studies that may be necessary to accomplish the objectives of this provision.

Sec. 507. Procurement of Re-refined Lubricating Oil and Retread Tires. (a) Agencies shall implement the EPA procurement guidelines for re-refined lubricating oil and retread tires. Fleet and commodity managers shall take immediate steps, as appropriate, to procure these items in accordance with section 6002 of RCRA. This provision does not preclude the acquisition of biobased (e.g., vegetable) oils.

(b) The FEE shall work to educate executive agencies about the new Department of Defense Cooperative Tire Qualification Program, including the Cooperative Approval Tire List and Cooperative Plant Qualification Program, as they apply to retread tires. 
Sec. 601. Agency Goals. (a)(1) Each agency shall establish either a goal for solid waste prevention and a goal for recycling or a goal for solid waste diversion to be achieved by J anuary 1, 2000. Each agency shall further ensure that the established goals include long-range goals to be achieved by the years 2005 and 2010 . These goals shall be submitted to the FEE within 180 days after the date of this order. (2) In addition to white paper, mixed paper/cardboard, aluminum, plastic, and glass, agencies should incorporate into their recycling programs efforts to recycle, reuse, or refurbish pallets and collect toner cartridges for remanufacturing. Agencies should also include programs to reduce or recycle, as appropriate, batteries, scrap metal, and fluorescent lamps and ballasts.

(b) Agencies shall set goals to increase the procurement of products that are made with recovered materials, in order to maximize the number of recycled products purchased, relative to non-recycled altematives.

(c) Each agency shall set a goal for increasing the use of environmentally preferable products and senvices for those products and services for which the agency has completed a pilot program.

(d) Agencies are encouraged to incorporate into their Govemment Performance Results Act annual performance plans the goals listed in subsections (a), (b), and (c) above, starting with the submittal to the Office of Management and Budget of the plan accompanying the FY 2001 budget

(e) Progress on attaining these goals should be reported by the agencies to the FEE for the biennial report specified in section 302(a)(2) of this order. 


\section{PART 7 - APPLICABILITY AND OTHER REQUIREMENTS}

Sec. 701. Contractor Applicability. Contracts that provide for contractor operation of a Govemment-owned or -leased facility and/or contracts that provide for contractor or other support services at Government-owned or -operated facilities awarded by executive agencies after the date of this order, shall include provisions that obligate the contractor to comply with the requirements of this order within the scope of its operations.

Sec. 702. Real Property Acquisition and Management. Within 90 days after the date of this order, and to the extent permitted by law and where economically feasible, executive agencies shall ensure compliance with the provisions of this order in the acquisition and management of Federally owned and leased space. The GSA and other executive agencies shall also include environmental and recycling provisions in the acquisition and management of all leased space and in the construction of new Federal buildings.

Sec. 703. Retention of Funds. (a) The Administrator of General Services shall continue with the program that retains for the agencies the proceeds from the sale of materials recovered through recycling or waste prevention programs and specifying the eligibility requirements for the materials being recycled.

(b) Agencies in non-GSA managed facilities, to the extent permitted by law, should develop a plan to retain the proceeds from the sale of materials recovered through recycling or waste prevention programs.

Sec. 704. Model Facility Programs. Each executive agency shall establish a model demonstration program incorporating some or all of the following elements as appropriate. Agencies are encouraged to demonstrate and test new and innovative approaches such as incorporating environmentally preferable and bio-based products; increasing the quantity and types of products containing recovered materials; expanding collection programs; implementing source reduction programs; composting 
organic materials when feasible; and exploring public/private partnerships to develop markets for recovered materials.

Sec. 705. Recycling Programs. (a)(1) Each executive agency that has not already done so shall initiate a program to promote cost-effective waste prevention and recycling of reusable materials in all of its facilities. The recycling programs implemented pursuant to this section must be compatible with applicable State and local recycling requirements.

(2) Agencies shall designate a recycling coordinator for each facility or installation. The recycling coordinator shall implement or maintain waste prevention and recycling programs in the agencies' action plans.

(b) Executive agencies shall also consider cooperative ventures with State and local governments to promote recycling and waste reduction in the community.

Sec. 706. Review of Implementation. The President's Council on Integrity and Efficiency shall request that the Inspectors General periodically review agencies' implementation of this order.

\section{PART 8 - AWARENESS}

Sec. 801. Training. (a) Within 180 days of the date of this order, the FEE and OFPP should evaluate the training courses provided by the Federal Acquisition Institute and the Defense Acquisition University and recommend any appropriate curriculum changes to ensure that procurement officials are aware of the requirements of this order.

(b) Executive agencies shall provide training to program management and requesting activities as needed to ensure awareness of the requirements of this order.

Sec. 802. Internal Agency Awards Programs. Each agency shall develop an internal agency-wide awards program, as appropriate, to 
reward its most innovative environmental programs. Among others, winners of agency-wide awards will be eligible for the White House Awards Program.

Sec. 803. White House Awards Program. A Government-wide award will be presented annually by the White House to the best, most innovative programs implementing the objectives of this order to give greater visibility to these efforts so that they can be incorporated Government-wide. The White House Awards Program will be administered jointly by the FEE and the CEQ.

\section{PART 9 - REVOCATION, LIMITATION, AND IMPLEMENTATION}

Sec. 901 . Executive Order 12873 of October 20, 1993, is hereby revoked.

Sec. 902. This order is intended only to improve the intemal management of the executive branch and is not intended to create any right, benefit, or trust responsibility, substantive or procedural, enforceable at law by a party against the United States, its agencies, its officers, or any other person.

Sec. 903. The policies and direction expressed in the EPA guidance to be developed pursuant to section 503 of this order shall be implemented and incorporated in the Federal Acquisition Regulation within 180 days after issuance of the guidance.

WILLIAM J . CLINTON

THE WHITE HOUSE, September 14, 1998. 


\section{B.5 Executive Order 13123}

THE WHITE HOUSE

Office of the Press Secretary

For Immediate Release

J une 3, 1999

\section{EXECUTIVE ORDER}

$$
-\cdot-\cdot-\cdot
$$

\section{GREENING THE GOVERNMENT THROUGH EFFICIENT ENERGY MANAGEMENT}

By the authority vested in me as President by the Constitution and the laws of the United States of America, including the National Energy Conservation Policy Act (Public Law 95-619, 92 Stat 3206, 42 U.S.C. 8252 et seq.), as amended by the Energy Policy Act of 1992 (EPACT) (Public Law 102-486, 106 Stat. 2776), and section 301 of title 3, United States Code, it is hereby ordered as follows:

\section{PART 1 - PREAMBLE}

Section 101. Federal Leadership. The Federal Government, as the Nation's largest energy consumer, shall significantly improve its energy management in order to save taxpayer dollars and reduce emissions that contribute to air pollution and global climate change. With more than 500,000 buildings, the Federal Govemment can lead the Nation in energy efficient building design, construction, and operation. As a major consumer that spends $\$ 200$ billion annually on products and services, the Federal Government can promote energy efficiency, water conservation, and the use of renewable energy products, and help foster markets for emerging technologies. In encouraging effective energy management in the Federal Govemment, this order builds on work begun under EPACT and previous Executive orders. 
PART 2 - GOALS

Sec. 201. Greenhouse Gases Reduction Goal. Through life-cycle cost-effective energy measures, each agency shall reduce its greenhouse gas emissions attributed to facility energy use by 30 percent by 2010 compared to such emissions levels in 1990. In order to encourage optimal investment in energy improvements, agencies can count greenhouse gas reductions from improvements in nonfacility energy use toward this goal to the extent that these reductions are approved by the Office of Management and Budget (OMB).

Sec. 202. Energy Efficiency Improvement Goals. Through life-cycle cost-effective measures, each agency shall reduce energy consumption per gross square foot of its facilities, excluding facilities covered in section 203 of this order, by 30 percent by 2005 and 35 percent by 2010 relative to 1985 . No facilities will be exempt from these goals unless they meet new criteria for exemptions, to be issued by the Department of Energy (DOE).

Sec. 203. Industrial and Laboratory Facilities. Through life-cycle cost-effective measures, each agency shall reduce energy consumption per square foot, per unit of production, or per other unit as applicable by 20 percent by 2005 and 25 percent by 2010 relative to 1990 . No facilities will be exempt from these goals unless they meet new criteria for exemptions, as issued by DOE.

Sec. 204. Renewable Energy. Each agency shall strive to expand the use of renewable energy within its facilities and in its activities by implementing renewable energy projects and by purchasing electricity from renewable energy sources. In support of the Million Solar Roofs initiative, the Federal Govemment shall strive to install 2,000 solar energy systems at Federal facilities by the end of 2000 , and 20,000 solar energy systems at Federal facilities by 2010.

Sec. 205. Petroleum. Through life-cycle cost-effective measures, each agency shall reduce the use of petroleum within its facilities. 
Agencies may accomplish this reduction by switching to a less greenhouse gas-intensive, nonpetroleum energy source, such as natural gas or renewable energy sources; by eliminating unnecessary fuel use; or by other appropriate methods. Where altemative fuels are not practical or life- cycle cost-effective, agencies shall strive to improve the efficiency of their facilities.

Sec. 206. Source Energy. The Federal Government shall strive to reduce total energy use and associated greenhouse gas and other air emissions, as measured at the source. To that end, agencies shall undertake life-cycle cost-effective projects in which source energy decreases, even if site energy use increases. In such cases, agencies will receive credit toward energy reduction goals through guidelines developed by DOE.

Sec. 207. Water Conservation. Through life-cycle cost-effective measures, agencies shall reduce water consumption and associated energy use in their facilities to reach the goals set under section 503(f) of this order. Where possible, water cost savings and associated energy cost savings shall be included in Energy Savings-Performance Contracts and other financing mechanisms.

\section{PART 3 - ORGANIZATION AND ACCOUNTABILITY}

Sec. 301. Annual Budget Submission. Each agency's budget submission to OMB shall specifically request funding necessary to achieve the goals of this order. Budget submissions shall include the costs associated with: encouraging the use of, administering, and fulfilling agency responsibilities under Energy-Savings Performance Contracts, utility energy-efficiency service contracts, and other contractual platforms for achieving conservation goals; implementing life-cycle cost-effective measures; procuring life-cycle cost-effective products; and constructing sustainably designed new buildings, among other energy costs. OMB shall issue guidelines to assist agencies in developing appropriate requests that support sound investments in energy improvements and energy-using products. OMB shall explore the feasibility of establishing a fund that agencies could draw on to finance exemplary energy management activities 
and investments with higher initial costs but lower life-cycle costs.

Budget requests to OMB in support of this order must be within each agency's planning guidance level.

Sec. 302. Annual Implementation Plan. Each agency shall develop an annual implementation plan for fulfilling the requirements of this order. Such plans shall be included in the annual reports to the President under section 303 of this order.

Sec. 303. Annual Reports to the President. (a) Each agency shall measure and report its progress in meeting the goals and requirements of this order on an annual basis. Agencies shall follow reporting guidelines as developed under section 306(b) of this order. In order to minimize additional reporting requirements, the guidelines will clarify how the annual report to the President should build on each agency's annual Federal energy reports submitted to DOE and the Congress. Annual reports to the President are due on J anuary 1 of each year beginning in the year 2000.

(b) Each agency's annual report to the President shall describe how the agency is using each of the strategies described in Part 4 of this order to help meet energy and greenhouse gas reduction goals. The annual report to the President shall explain why certain strategies, if any, have not been used. It shall also include a listing and explanation of exempt facilities.

Sec. 304. Designation of Senior Agency Official. Each agency shall designate a senior official, at the Assistant Secretary level or above, to be responsible for meeting the goals and requirements of this order, including preparing the annual report to the President. Such designation shall be reported by each Cabinet Secretary or agency head to the Deputy Director for Management of OMB within 30 days of the date of this order. Designated officials shall participate in the Interagency Energy Policy Committee, described in section 306(d) of this order. The Committee shall communicate its activities to all designated officials to assure proper coordination and achievement of the goals and requirements of this order. 
Sec. 305. Designation of Agency Energy Teams. Within 90 days of the date of this order, each agency shall form a technical support team consisting of appropriate procurement, legal, budget, management, and technical representatives to expedite and encourage the agency's use of appropriations, Energy-Savings Performance Contracts, and other altemative financing mechanisms necessary to meet the goals and requirements of this order. Agency energy team activities shall be undertaken in collaboration with each agency's representative to the Interagency Energy Management Task Force, as described in section 306(e) of this order.

Sec. 306. Interagency Coordination. (a) Office of Management and Budget The Deputy Director for Management of OMB, in consultation with DOE, shall be responsible for evaluating each agency's progress in improving energy management and for submitting agency energy scorecards to the President to report progress.

(1) OMB, in consultation with DOE and other agencies, shall develop the agency energy scorecards and scoring system to evaluate each agency's progress in meeting the goals of this order. The scoring criteria shall include the extent to which agencies are taking advantage of key tools to save energy and reduce greenhouse gas emissions, such as Energy Savings Performance Contracts, utility energy-efficiency service contracts, ENERGY STAR (Registered Trademark) and other energy efficient products, renewable energy technologies, electricity from renewable energy sources, and other strategies and requirements listed in Part 4 of this order, as well as overall efficiency and greenhouse gas metrics and use of other innovative energy efficiency practices. The scorecards shall be based on the annual energy reports submitted to the President under section 303 of this order.

(2) The Deputy Director for Management of OMB shall also select outstanding agency energy management team(s), from among candidates nominated by DOE, for a new annual Presidential award for energy efficiency. 
(b) Federal Energy Management Program. The DOE's Federal Energy Management Program (FEMP) shall be responsible for working with the agencies to ensure that they meet the goals of this order and report their progress. FEMP, in consultation with OMB, shall develop and issue guidelines for agencies' preparation of their annual reports to the President on energy management, as required in section 303 of this order. FEMP shall also have primary responsibility for collecting and analyzing the data, and shall assist OMB in ensuring that agency reports are received in a timely manner.

(c) President's Management Council. The President's Management Council (PMC), chaired by the Deputy Director for Management of OMB and consisting of the Chief Operating Officers (usually the Deputy Secretary) of the largest Federal departments and agencies, will periodically discuss agencies' progress in improving Federal energy management.

(d) Interagency Energy Policy Committee. This Committee was established by the Department of Energy Organization Act It consists of senior agency officials designated in accordance with section 304 of this order. The Committee is responsible for encouraging implementation of energy efficiency policies and practices. The major energy-consuming agencies designated by DOE are required to participate in the Committee. The Committee shall communicate its activities to all designated senior agency officials to promote coordination and achievement of the goals of this order.

(e) Interagency Energy Management Task Force. The Task Force was established by the National Energy Conservation Policy Act. It consists of each agency's chief energy manager. The Committee shall continue to work toward improving agencies' use of energy management tools and sharing information on Federal energy management across agencies.

Sec. 307. Public/Private Advisory Committee. The Secretary of Energy will appoint an advisory committee consisting of representatives from Federal agencies, State governments, energy service companies, utility companies, equipment manufacturers, construction and 
architectural companies, environmental, energy and consumer groups, and other energy-related organizations. The committee will provide input on Federal energy management, including how to improve use of Energy-Savings Performance Contracts and utility energy-efficiency service contracts, improve procurement of ENERGY STAR (Registered Trademark) and other energy efficient products, improve building design, reduce process energy use, and enhance applications of efficient and renewable energy technologies at Federal facilities.

Sec. 308. Applicability. This order applies to all Federal departments and agencies. General Senvices Administration (GSA) is responsible for working with agencies to meet the requirements of this order for those facilities for which GSA has delegated operations and maintenance authority. The Department of Defense (DOD) is subject to this order to the extent that it does not impair or adversely affect military operations and training (including tactical aircraft, ships, weapons systems, combat training, and border security).

\section{PART 4 - PROMOTING FEDERAL LEADERSHIP IN ENERGY MANAGEMENT}

Sec. 401. Life-Cycle Cost Analysis. Agencies shall use life-cycle cost analysis in making decisions about their investments in products, services, construction, and other projects to lower the Federal Government's costs and to reduce energy and water consumption. Where appropriate, agencies shall consider the life-cycle costs of combinations of projects, particularly to encourage bundling of energy efficiency projects with renewable energy projects. Agencies shall also retire inefficient equipment on an accelerated basis where replacement results in lower life-cycle costs. Agencies that minimize life- cycle costs with efficiency measures will be recognized in their scorecard evaluations.

Sec. 402. Facility Energy Audits. Agencies shall continue to conduct energy and water audits for approximately 10 percent of their facilities each year, either independently or through Energy-Savings Performance Contracts or utility energy-efficiency service contracts. 
Sec. 403. Energy Management Strategies and Tools. Agencies shall use a variety of energy management strategies and tools, where life-cycle cost-effective, to meet the goals of this order. An agency's use of these strategies and tools shall be taken into account in assessing the agency's progress and formulating its score card.

(a) Financing Mechanisms. Agencies shall maximize their use of available alternative financing contracting mechanisms, including Energy-Savings Performance Contracts and utility energy-efficiency service contracts, when life-cycle cost-effective, to reduce energy use and cost in their facilities and operations. Energy-Savings Performance Contracts, which are authorized under the National Energy Conservation Policy Act, as modified by the Energy Policy Act of 1992, and utility energy-efficiency service contracts provide significant opportunities for making Federal facilities more energy efficient at no net cost to taxpayers.

(b) ENERGY STAR (Registered Trademark)and Other Energy Efficient Products.

(1) Agencies shall select, where life-cycle cost-effective, ENERGY STAR? and other energy efficient products when acquiring energy-using products. For product groups where ENERGY STAR (Registered Trademark) labels are not yet available, agencies shall select products that are in the upper 25 percent of energy efficiency as designated by FEMP. The Environmental Protection Agency (EPA) and DOE shall expedite the process of designating products as ENERGY STAR (Registered Trademark) and will merge their current efficiency rating procedures.

(2) GSA and the Defense Logistics Agency (DLA), with assistance from EPA and DOE, shall create clear catalogue listings that designate these products in both print and electronic formats. In addition, GSA and DLA shall undertake pilot projects from selected energy-using products to show a "second price tag", which means an accounting of the operating and purchase costs of the item, in both printed and electronic catalogues and assess the impact of providing this information on Federal purchasing decisions. 
(3) Agencies shall incorporate energy efficient criteria consistent with ENERGY STAR (Registered Trademark)and other FEMPdesignated energy efficiency levels into all guide specifications and project specifications developed for new construction and renovation, as well as into product specification language developed for Basic Ordering Agreements, Blanket Purchasing Agreements, Govemment Wide Acquisition Contracts, and all other purchasing procedures.

(4) DOE and OMB shall also explore the creation of financing agreements with private sector suppliers to provide private funding to offset higher up-front costs of efficient products. Within 9 months of the date of this order, DOE shall report back to the President's Management Council on the viability of such altemative financing options.

(c) ENERGY STAR (Registered Trademark) Buildings. Agencies shall strive to meet the ENERGY STAR (Registered Trademark) Building criteria for energy performance and indoor environmental quality in their eligible facilities to the maximum extent practicable by the end of 2002. Agencies may use Energy-Savings Performance Contracts, utility energy-efficiency service contracts, or other means to conduct evaluations and make improvements to buildings in order to meet the criteria. Buildings that rank in the top 25 percent in energy efficiency relative to comparable commercial and Federal buildings will receive the ENERGY STAR (Registered Trademark) building label. Agencies shall integrate this building rating tool into their general facility audits.

(d) Sustainable Building Design. DOD and GSA, in consultation with DOE and EPA, shall develop sustainable design principles. Agencies shall apply such principles to the siting, design, and construction of new facilities. Agencies shall optimize life-cycle costs, pollution, and other environmental and energy costs associated with the construction, life-cycle operation, and decommissioning of the facility. Agencies shall consider using Energy-Savings Performance Contracts or 
utility energy-efficiency service contracts to aid them in constructing sustainably designed buildings.

(e) Model Lease Provisions. Agencies entering into leases, including the renegotiation or extension of existing leases, shall incorporate lease provisions that encourage energy and water efficiency wherever life-cycle cost-effective. Build-to-suit lease solicitations shall contain criteria encouraging sustainable design and development, energy efficiency, and verification of building performance. Agencies shall include a preference for buildings having the ENERGY STAR? building label in their selection criteria for acquiring leased buildings. In addition, all agencies shall encourage lessors to apply for the ENERGY STAR (Registered Trademark) building label and to explore and implement projects that would reduce costs to the Federal Government, including projects carried out through the lessors' Energy-Savings Performance Contracts or utility energy-efficiency service contracts.

(f) Industrial Facility Efficiency Improvements. Agencies shall explore efficiency opportunities in industrial facilities for steam systems, boiler operation, air compressor systems, industrial processes, and fuel switching, including cogeneration and other efficiency and renewable energy technologies.

(g) Highly Efficient Systems. Agencies shall implement district energy systems, and other highly efficient systems, in new construction or retrofit projects when life-cycle cost-effective. Agencies shall consider combined cooling, heat, and power when upgrading and assessing facility power needs and shall use combined cooling, heat, and power systems when life-cycle cost-effective. Agencies shall survey local natural resources to optimize use of available biomass, bioenergy, geothermal, or other naturally occurring energy sources.

(h) Off-Grid Generation. Agencies shall use off-grid generation systems, including solar hot water, solar electric, solar outdoor lighting, small wind turbines, fuel cells, and other off-grid alternatives, where such systems are life-cycle cost-effective and offer 
benefits including energy efficiency, pollution prevention, source energy reductions, avoided infrastructure costs, or expedited service.

Sec. 404. Electricity Use. To advance the greenhouse gas and renewable energy goals of this order, and reduce source energy use, each agency shall strive to use electricity from clean, efficient, and renewable energy sources. An agency's efforts in purchasing electricity from efficient and renewable energy sources shall be taken into account in assessing the agency's progress and formulating its score card.

(a) Competitive Power. Agencies shall take advantage of competitive opportunities in the electricity and natural gas markets to reduce costs and enhance services. Agencies are encouraged to aggregate demand across facilities or agencies to maximize their economic advantage.

(b) Reduced Greenhouse Gas Intensity of Electric Power. When selecting electricity providers, agencies shall purchase electricity from sources that use high efficiency electric generating technologies when life-cycle cost-effective. Agencies shall consider the greenhouse gas intensity of the source of the electricity and strive to minimize the greenhouse gas intensity of purchased electricity.

(c) Purchasing Electricity from Renewable Energy Sources.

(1) Each agency shall evaluate its current use of electricity from renewable energy sources and report this level in its annual report to the President. Based on this review, each agency should adopt policies and pursue projects that increase the use of such electricity. Agencies should include provisions for the purchase of electricity from renewable energy sources as a component of their requests for bids whenever procuring electricity. Agencies may use savings from energy efficiency projects to pay additional incremental costs of electricity from renewable energy sources:

(2) In evaluating opportunities to comply with this section, agencies should consider: my Administration's goal of tripling nonhydroelectric renewable energy capacity in the United States by 2010; the renewable portfolio standard specified in the restructuring 
guidelines for the State in which the facility is located; GSA's efforts to make electricity from renewable energy sources available to Federal electricity purchasers; and EPA's guidelines on crediting renewable energy power in implementation of Clean Air Act standards.

Sec. 405. Mobile Equipment Each agency shall seek to improve the design, construction, and operation of its mobile equipment, and shall implement all life-cycle cost-effective energy efficiency measures that result in cost savings while improving mission performance. To the extent that such measures are life-cycle cost-effective, agencies shall consider enhanced use of alternative or renewable-based fuels.

Sec. 406. Management and Govemment Performance. Agencies shall use the following management strategies in meeting the goals of this order.

(a) Awards. Agencies shall use employee incentive programs to reward exceptional performance in implementing this order.

(b) Performance Evaluations. Agencies shall include successful implementation of provisions of this order in areas such as Energy-Savings Performance Contracts, sustainable design, energy efficient procurement, energy efficiency, water conservation, and renewable energy projects in the position descriptions and performance evaluations of agency heads, members of the agency energy team, principal program managers, heads of field offices, facility managers, energy managers, and other appropriate employees.

(c) Retention of Savings and Rebates. Agencies granted statutory authority to retain a portion of savings generated from efficient energy and water management are encouraged to permit the retention of the savings at the facility or site where the savings occur to provide greater incentive for that facility and its site managers to undertake more energy management initiatives, invest in renewable energy systems, and purchase electricity from renewable energy sources. 
(d) Training and Education. Agencies shall ensure that all appropriate personnel receive training for implementing this order.

(1) DOE, DOD, and GSA shall provide relevant training or training materials for those programs that they make available to all Federal agencies relating to the energy management strategies contained in this order.

(2) The Federal Acquisition Institute and the Defense Acquisition University shall incorporate into existing procurement courses information on Federal energy management tools, including Energy Savings Performance Contracts, utility energy-efficiency senvice contracts, ENERGY STAR (Registered Trademark) and other energy efficient products, and life-cycle cost analysis.

(3) All agencies are encouraged to develop outreach programs that include education, training, and promotion of ENERGY STAR (Registered Trademark) and other energy-efficient products for Federal purchase card users. These programs may include promotions with billing statements, user training, catalogue awareness, and exploration of vendor data collection of purchases.

(e) Showcase Facilities. Agencies shall designate exemplary new and existing facilities with significant public access and exposure as showcase facilities to highlight energy or water efficiency and renewable energy improvements.

\section{PART 5 -- TECHNICAL ASSISTANCE}

Sec. 501. Within 120 days of this order, the Director of OMB shall:

(a) develop and issue guidance to agency budget officers on preparation of annual funding requests associated with the implementation of the order for the FY 2001 budget; 
(b) in collaboration with the Secretary of Energy, explain to agencies how to retain savings and reinvest in other energy and water management projects; and

(c) in collaboration with the Secretary of Energy through the Office of Federal Procurement Policy, periodically brief agency procurement executives on the use of Federal energy management tools, including Energy-Savings Performance Contracts, utility energy-efficiency service contracts, and procurement of energy efficient products and electricity from renewable energy sources.

Sec. 502. Within 180 days of this order, the Secretary of Energy, in collaboration with other agency heads, shall:

(a) issue guidelines to assist agencies in measuring energy per square foot, per unit of production, or other applicable unit in industrial, laboratory, research, and other energy-intensive facilities;

(b) establish criteria for determining which facilities are exempt from the order. In addition, DOE must provide guidance for agencies to report proposed exemptions;

(c) develop guidance to assist agencies in calculating appropriate energy baselines for previously exempt facilities and facilities occupied after 1990 in order to measure progress toward goals;

(d) issue guidance to clarify how agencies determine the life-cycle cost for investments required by the order, including how to compare different energy and fuel options and assess the current tools;

(e) issue guidance for providing credit toward energy efficiency goals for cost-effective projects where source energy use declines but site energy use increases; and

(f) provide guidance to assist each agency to determine a baseline of water consumption. 
Sec. 503. Within 1 year of this order, the Secretary of Energy, in collaboration with other agency heads, shall:

(a) provide guidance for counting renewable and highly efficient energy projects and purchases of electricity from renewable and highly efficient energy sources toward agencies' progress in reaching greenhouse gas and energy reduction goals;

(b) develop goals for the amount of energy generated at Federal facilities from renewable energy technologies;

(c) support efforts to develop standards for the certification of low environmental impact hydropower facilities in order to facilitate the Federal purchase of such power;

(d) work with GSA and DLA to develop a plan for purchasing advanced energy products in bulk quantities for use in by multiple agencies;

(e) issue guidelines for agency use estimating the greenhouse gas emissions attributable to facility energy use. These guidelines shall include emissions associated with the production, transportation and use of energy consumed in Federal facilities; and

(f) establish water conservation goals for Federal agencies.

Sec. 504. Within 120 days of this order, the Secretary of Defense and the Administrator of GSA, in consultation with other agency heads, shall develop and issue sustainable design and development principles for the siting, design, and construction of new facilities.

Sec. 505. Within 180 days of this order, the Administrator of GSA, in collaboration with the Secretary of Defense, the Secretary of Energy, and other agency heads, shall:

(a) develop and issue guidance to assist agencies in ensuring that all project cost estimates, bids, and agency budget requests for design, construction, and renovation of facilities are based on life-cycle 
costs. Incentives for contractors involved in facility design and construction must be structured to encourage the contractors to design and build at the lowest life-cycle cost;

(b) make information available on opportunities to purchase electricity from renewable energy sources as defined by this order. This information should accommodate relevant State regulations and be updated periodically based on technological advances and market changes, at least every 2 years;

(c) develop Internet-based tools for both GSA and DLA customers to assist individual and agency purchasers in identifying and purchasing ENERGY STAR? and other energy efficient products for acquisition; and

(d) develop model lease provisions that incorporate energy efficiency and sustainable design. PART 6 -- GENERAL PROVISIONS

Sec. 601. Compliance by Independent Agencies. Independent agencies are encouraged to comply with the provisions of this order.

Sec. 602. Waivers. If an agency determines that a provision in this order is inconsistent with its mission, the agency may ask DOE for a waiver of the provision. DOE will include a list of any waivers it grants in its Federal Energy Management Programs annual report to the Congress.

Sec. 603. Scope. (a) This order is intended only to improve the internal management of the Executive branch and is not intended to create any right, benefit, or trust responsibility, substantive or procedural, enforceable by law by a party against the United States, its agencies, its officers, or any other person.

(b) This order applies to agency facilities in any State of the United States, the District of Columbia, the Commonwealth of Puerto Rico, Guam, American Samoa, the United States Virgin Islands, the Northern Mariana Islands, and any other territory or possession over which the United States has jurisdiction. Agencies with facilities 
outside of these areas, however, are encouraged to make best efforts to comply with the goals of this order for those facilities. In addition, agencies can report energy improvements made outside the United States in their annual report to the President; these improvements may be considered in agency scorecard evaluations.

Sec. 604. Revocations. Executive Order 12902 of March 9, 1994, Executive Order 12759 of April 17, 1991, and Executive Order 12845 of April 21, 1993, are revoked.

Sec. 605. Amendments to Federal Regulations. The Federal Acquisition Regulation and other Federal regulations shall be amended to reflect changes made by this order, including an amendment to facilitate agency purchases of electricity from renewable energy sources.

\section{PART 7 -- DEFINITIONS}

For the purposes of this order:

Sec. 701. "Acquisition" means acquiring by contract supplies or services (including construction) by and for the use of the Federal Government through purchase or lease, whether the supplies or services are already in existence or must be created, developed, demonstrated, and evaluated. Acquisition begins at the point when agency needs are established and includes the description of requirements to satisfy agency needs, solicitation and selection of sources, award of contracts, contract financing, contract performance, contract administration, and those technical and management functions directly related to the process of fulfilling agency needs by contract

Sec. 702. "Agency" means an Executive agency as defined in 5 U.S.C. 105. For the purpose of this order, military departments, as defined in 5 U.S.C. 102, are covered under the auspices of DOD.

Sec. 703. "Energy-Savings Performance Contract" means a contract that provides for the performance of services for the design, acquisition, financing, installation, testing, operation, and where 
appropriate, maintenance and repair, of an identified energy or water conservation measure or series of measures at one or more locations. Such contracts shall provide that the contractor must incur costs of implementing energy savings measures, including at least the cost (if any) incurred in making energy audits, acquiring and installing equipment, and training personnel in exchange for a predetermined share of the value of the energy savings directly resulting from implementation of such measures during the term of the contract Payment to the contractor is contingent upon realizing a guaranteed stream of future energy and cost savings. All additional savings will accrue to the Federal Govemment

Sec. 704. "Exempt facility" or "Exempt mobile equipment" means a facility or a piece of mobile equipment for which an agency uses DOE-established criteria to determine that compliance with the Energy Policy Act of 1992 or this order is not practical.

Sec. 705. "Facility" means any individual building or collection of buildings, grounds, or structure, as well as any fixture or part thereof, including the associated energy or water-consuming support systems, which is constructed, renovated, or purchased in whole or in part for use by the Federal Government. It includes leased facilities where the Federal Government has a purchase option or facilities planned for purchase. In any provision of this order, the term "facility" also includes any building 100 percent leased for use by the Federal Government where the Federal Government pays directly or indirectly for the utility costs associated with its leased space. The term also includes Government-owned contractor-operated facilities.

Sec. 706. "Industrial facility" means any fixed equipment, building, or complex for production, manufacturing, or other processes that uses large amounts of capital equipment in connection with, or as part of, any process or system, and within which the majority of energy use is not devoted to the heating, cooling, lighting, ventilation, or to service the water heating energy load requirements of the facility. 
Sec. 707. "Life-cycle costs" means the sum of the present values of investment costs, capital costs, installation costs, energy costs, operating costs, maintenance costs, and disposal costs, over the lifetime of the project, product, or measure. Additional guidance on measuring life-cycle costs is specified in 10 C.F.R. 436.19.

Sec. 708. "Life-cycle cost-effective" means the life-cycle costs of a product, project, or measure are estimated to be equal to or less than the base case (i.e., current or standard practice or product). Additional guidance on measuring cost-effectiveness is specified in 10 C.F.R. 436.18 (a), (b), and (c), 436.20, and 436.21.

Sec. 709. "Mobile equipment" means all Federally owned ships, aircraft, and nonroad vehicles.

Sec. 710. "Renewable energy" means energy produced by solar, wind, geothermal, and biomass power.

Sec. 711. "Renewable energy technology" means technologies that use renewable energy to provide light, heat, cooling, or mechanical or electrical energy for use in facilities or other activities. The term also means the use of integrated whole-building designs that rely upon renewable energy resources, including passive solar design.

Sec. 712. "Source energy" means the energy that is used at a site and consumed in producing and in delivering energy to a site, including, but not limited to, power generation, transmission, and distribution losses, and that is used to perform a specific function, such as space conditioning, lighting or water heating.

Sec. 713. "Utility" means public agencies and privately owned companies that market, generate, and/or distribute energy or water, including electricity, natural gas, manufactured gas, steam, hot water, and chilled water as commodities for public use and that provide the senvice under Federal, State, or local regulated authority to all authorized customers. Utilities include: Federally owned non-profit producers; municipal organizations; and investor or privately owned 
producers regulated by a State and/or the Federal Govemment;

cooperatives owned by members and providing services mostly to their

members; and other nonprofit State and local government agencies serving

in this capacity.

Sec. 714. "Utility energy-efficiency service" means demand side management services provided by a utility to improve the efficiency of use of the commodity (electricity, gas, etc.) being distributed.

Services can include, but are not limited to, energy efficiency and renewable energy project auditing, financing, design, installation, operation, maintenance, and monitoring.

WILLIAM J . CLINTON

THE WHITE HOUSE, J une 3, 1999. 